\title{
Molecular Mechanisms Driving Progression of Liver Cirrhosis towards Hepatocellular Carcinoma in Chronic Hepatitis B and C Infections: A Review
}

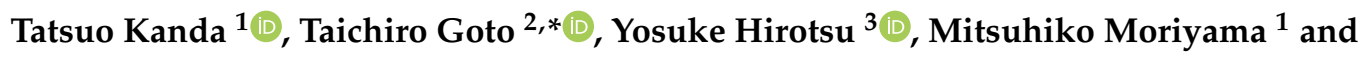 \\ Masao Omata ${ }^{3,4}$ \\ 1 Division of Gastroenterology and Hepatology, Department of Medicine, Nihon University School of \\ Medicine, 30-1 Oyaguchi-kamicho, Itabashi-ku, Tokyo 173-8610, Japan; kanda2t@yahoo.co.jp (T.K.); \\ moriyama.mitsuhiko@nihon-u.ac.jp (M.M.) \\ 2 Lung Cancer and Respiratory Disease Center, Yamanashi Central Hospital, 1-1-1 Fujimi, Kofu, \\ Yamanashi 400-8506, Japan \\ 3 Genome Analysis Center, Yamanashi Central Hospital, Yamanashi 400-8506, Japan; \\ hirotsu-bdyu@ych.pref.yamanashi.jp (Y.H.); m-omata0901@ych.pref.yamanashi.jp (M.O.) \\ 4 The University of Tokyo, 7-3-1 Hongo, Bunkyo-ku, Tokyo 113-8655, Japan \\ * Correspondence: taichiro@1997.jukuin.keio.ac.jp; Tel.: +81-55-253-7111
}

Received: 19 January 2019; Accepted: 14 March 2019; Published: 18 March 2019

\begin{abstract}
Almost all patients with hepatocellular carcinoma (HCC), a major type of primary liver cancer, also have liver cirrhosis, the severity of which hampers effective treatment for HCC despite recent progress in the efficacy of anticancer drugs for advanced stages of HCC. Here, we review recent knowledge concerning the molecular mechanisms of liver cirrhosis and its progression to HCC from genetic and epigenomic points of view. Because $70 \%$ of patients with HCC have hepatitis $B$ virus (HBV) and/or hepatitis C virus (HCV) infection, we focused on HBV- and HCV-associated HCC. The literature suggests that genetic and epigenetic factors, such as microRNAs, play a role in liver cirrhosis and its progression to HCC, and that HBV- and HCV-encoded proteins appear to be involved in hepatocarcinogenesis. Further studies are needed to elucidate the mechanisms, including immune checkpoints and molecular targets of kinase inhibitors, associated with liver cirrhosis and its progression to HCC.
\end{abstract}

Keywords: cirrhosis; HBV; HCV; hepatocellular carcinoma

\section{Introduction}

Almost all patients with hepatocellular carcinoma (HCC), a major type of primary liver cancer, have liver cirrhosis [1], the severity of which can prevent effective treatment for HCC despite recent progress in the efficacy of anticancer drugs for advanced stages of HCC [2-7]. Because most patients with liver cirrhosis are asymptomatic, it is difficult to diagnose early stages of HCC [8], and patients with hepatic symptoms and HCC are considered to have advanced-stage HCC [8,9]. These issues explain the prevalence of poor prognosis for HCC patients.

HCC is the 4 th most common neoplasm and the 2 nd commonest cause of cancer deaths in the world. Notably, HCC is a male-dominant disease, with the incidence of HCC $\sim 3$-fold higher in males than in females [10]. Hepatitis B virus (HBV) infection is associated with the higher HCC incidence in persons with cirrhosis, occurring in high endemic areas and in Western countries (5-year cumulative incidence, $15 \%$ and $10 \%$, respectively) [11]. In hepatitis C virus (HCV)-related cirrhosis, the 5-year cumulative HCC risk is $30 \%$ in Japan and 17\% in Western countries [11]. 
Histologically, liver fibrosis involves the deposition of extracellular matrix proteins, including collagen, in higher-order structures within hepatic parenchyma [12,13], with hepatic stellate cells and fibroblasts representing major producers of collagen [14]. The histological pattern of liver fibrosis is not unique, and the extent and distribution of liver fibrosis exhibits various patterns depending on different etiologies [12,15]. Excessive liver fibrosis often develops within portal tracts and extends into the hepatic parenchyma in viral hepatitis, with these activities appearing to be associated with persistent portal inflammation [12,16]. Bridging fibrosis appears following the development of periportal fibrosis and extends across lobules to connect mesenchymal structures (portal tracts and central veins) to different extents. Generally, these processes accompany intrahepatic portosystemic vascular shunting and regeneration of hepatocytes, thereby transforming from normal hepatic architecture to nodule formation and finally establishing the structure of cirrhosis [12].

In this review, we discuss the molecular mechanisms underlying the progression of liver cirrhosis to HCC. We expect that this review will help clinicians diagnose and treat patients with liver cirrhosis and / or HCC in their daily clinical practice. Notably, $70 \%$ of HCC patients are afflicted with HBV or HCV infection [11]; therefore, we focused on the occurrence of HCC during HBV and HCV infection (Figure 1).

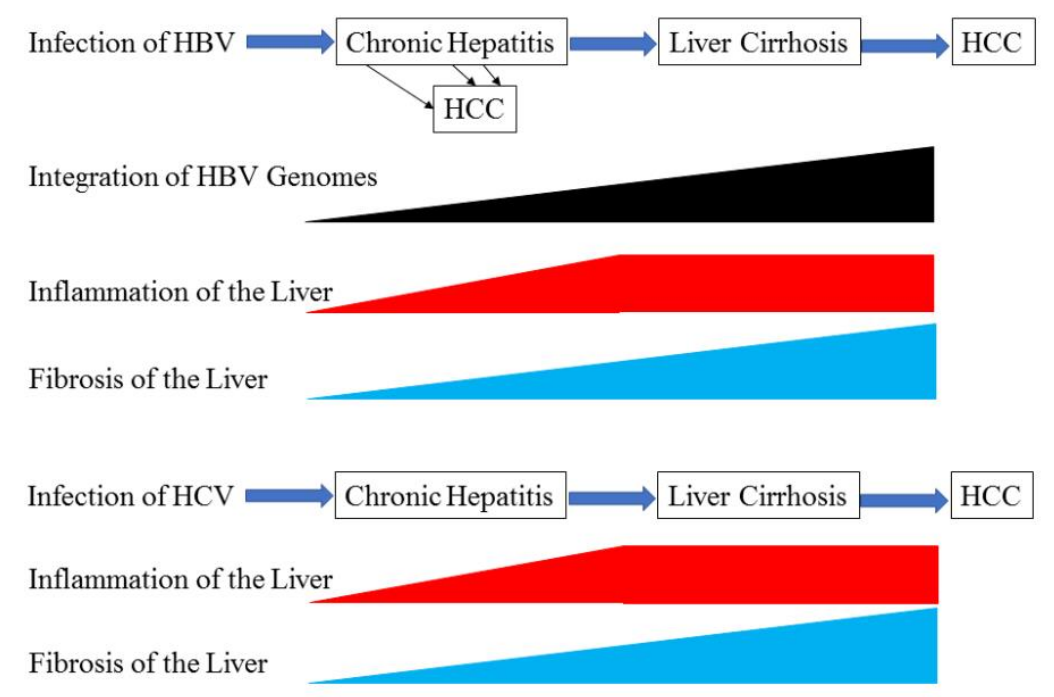

Figure 1. Occurrence of HCC in natural course of HBV and HCV infection.

\section{Liver Cirrhosis and Its Progression to HCC with HBV Infection}

\subsection{Development of Liver Cirrhosis in Patients with Chronic Hepatitis B Infection}

HBV infection causes acute and chronic hepatitis, cirrhosis, and HCC. HBV-carrier rates are higher in African and Asian countries and globally are estimated to have resulted in 786,000 deaths in 2010, the majority of which were attributed to HCC (341,400 deaths) and cirrhosis (312,400 deaths) [17]. Annual rates of development from chronic hepatitis B to liver cirrhosis ranged from 2.1 to $6.0 \%$ [18-21], and annual rates of the development of liver cirrhosis in HBV e antigen (HBeAg)-positive or anti-HBe-positive patients were $2.4 \%$ and $1.3 \%$, respectively [18].

HBeAg-positivity and elevated HBV DNA levels are risk factors for the development of liver cirrhosis in patients with chronic hepatitis B [19]. Sumi et al. [20] reported that progression to cirrhosis is slower in HBV genotype B than that in HBV genotype $C$ infection. Additionally, for patients with chronic hepatitis B infection, coinfection with HCV or human immunodeficiency virus (HIV) is another risk factor for the development of liver cirrhosis [21,22].

Older age ( $\geq 55$ years), male gender, chronic active hepatitis, higher alanine aminotransferase (ALT) levels, history of decompensation, ferredoxin-1-associated single-nucleotide polymorphism, 
HLA-DQA2 rs9276370 variants, and HLA-DQB2 rs7756516 variants are also respective risk factors for the development of liver cirrhosis [18-21,23-25].

\subsection{Development of HCC in Patients with HBV-related Liver Cirrhosis}

Annual rates of occurrence of HCC in patients with HBV-related cirrhosis are 2.3\% [1]. Higher HBV DNA levels, HBeAg-positivity, higher HBV surface antigen (HBsAg) levels, HBV genotype C, and basal core-promoter mutations are viral risk factors for the occurrence of HCC, and older age, male gender, chronic active hepatitis, higher ALT levels, and higher $\alpha$-fetoprotein levels are non-viral risk factors for the occurrence of HCC $[20,23,26]$. Treatment with nucleos(t)ide analogs for HBV control decreases the occurrence rates of HCC in patients with HBV-related cirrhosis [27].

\section{Liver Cirrhosis and Its Progression to HCC with HCV Infection}

HCV infection causes acute and chronic hepatitis, cirrhosis, and HCC. In 2015, there were 170,000 new HCV infections [28], with annual incidence rates of cirrhosis accompanying HCV infection at $1.1 \%$ [29]. Forns et al. [30] reported that chronic HCV infection displayed a high rate of progression to liver cirrhosis over a prolonged follow-up period, and that an aspartate aminotransferase (AST) value $>70 \mathrm{IU} / \mathrm{L}$ was associated with cirrhosis development [odds ratio (OR): 4.22, 95\% confidence interval (CI): 1.3-13.8]. Additionally, there is an association between HCV genotype 3 and steatosis, which accelerates fibrosis development over time in HCV genotype 3-infected patients [31,32]. Moreover, previous studies reported that exposure to $\mathrm{HCV}$ at a young age is associated with a reduced rate of fibrosis progression [33-37], and that liver fibrosis progression was mainly dependent on the age and duration of infection [36]. The evidences are growing that liver steatosis and diabetes mellitus are factors affecting progression to HCC in HCV-infected patients with compensated cirrhosis [11]. These comorbidities typically affecting aged patients might explain the increased malignant progression of the cirrhotic liver damage. Ongoing alcohol consumption and severe inflammation according to liver histology are also associated with liver fibrosis progression [35-37]. A multivariate analysis of HCV-infected patients [38] revealed that only male sex (OR: $3.17,95 \%$ CI: 1.152-8.773) and HIV infection (OR: 6.85, 95\% CI: 2.93-16.005) were associated with advanced liver fibrosis. Furthermore, HBsAg-positive HCV-coinfected patients are at high risk of developing liver disease [39], and injected-drug users [40]; patients with insulin resistance or diabetes [41]; and patients with concurrent obesity, diabetes, and steatosis [42] are also at risk of advanced liver fibrosis. Following antiviral treatment, sustained virological response (SVR) can reduce liver fibrosis progression in most patients infected with HCV [43].

Annual rates of HCC occurrence in patients with HCV-related cirrhosis are $~ 4.5 \%$ [1]. Caporaso et al. [44] found that mean age and male/female ratio were significantly higher in patients with HCC plus liver cirrhosis than in those with liver cirrhosis alone. Additionally, HBsAg-positive HCV-coinfected patients with liver cirrhosis are at a high risk of developing HCC [45], with elevated ALT levels [46] and hepatic steatosis [47] risk factors for the development of HCC in patients with HCV-related liver cirrhosis. SVR can reduce HCC development in most patients infected with HCV-related liver cirrhosis [48], although changes in the risk of HCC development following HCV eradication with direct-acting antivirals (DAAs) is controversial [49-51]. Further studies will be needed in DAA-era.

\section{Molecular Mechanisms of Liver Cirrhosis and Its Progression to HCC}

Accumulation of genetic mutations occurs during HCC progression. Recent advances in next-generation sequencing technology to augment Sanger sequencing enabled whole-genome sequencing to allow critical insights into the molecular mechanisms associated with this activity.

\subsection{Driver-Gene Candidates in HCC}

Totoki et al. [52] found 30 candidate driver genes [telomerase reverse transcriptase (TERT), catenin $\beta 1$ (CTNNB1), tumor protein p53 (TP53), AT-rich interaction domain 2 (ARID2), axin 1 (AXIN1), TSC 
complex subunit 2 (TSC2), retinoblastoma protein 1 (RB1), activin A receptor type 2A (ACVR2A), bromodomain containing 7 (BRD7), cyclin dependent kinase inhibitor (CDKN)1A, menin 1 (MEN1), polypeptide N-acetylgalactosaminyltransferase 11 (GALN11), fibroblast growth factor 19 (FGF19), cyclin (CCN)D1, AT-rich interaction domain 1A (ARID1A), CDKN2A, CDKN2B, ribosomal protein S6 kinase, $90 \mathrm{kDa}$, polypeptide 3 (RPS6KA3), nuclear factor, erythroid 2 like 2 (NFE2L2), nuclear receptor corepressor 1 (NCOR1), alcohol dehydrogenase 1B, $\beta$ polypeptide (ADH1B), Snf2-related CREB binding protein (CREBBP) activator protein (SRCAP), Fc receptor like 1 (FCRL1), phosphatase and tensin homolog (PTEN), heterogeneous nuclear ribonucleoprotein A2/B1 (HNRNPA2B1), cytochrome P450 family 2 subfamily E member 1 (CYP2E1), mitogen-activated protein kinase 3 (MAP2K3), tuberous sclerosis (TSC)1, transmembrane protein 99 (TMEM99), and glucose-6-phosphatase, catalytic subunit (G6PC)] and 11 core pathway modules [ $\beta$-catenin, chromatin remodeling, DNA repair, estrogen-related receptor beta (ERRB), fibrinogen, mechanistic target of rapamycin kinase (mTOR), synaptic connection, TERT, p53, NOTCH, and NCOR] through the collection of data from 503 HCC genomes from different populations (Table 1).

Fujimoto et al. [53] identified 15 significantly mutated genes, including TP53, ERBB-receptor feedback inhibitor 1, Zic family member 3, CTNNB1, glucoside xylosyltransferase 1, otopetrin 1, albumin (ALB), ATM serine/threonine kinase (ATM), zinc finger protein 226, ubiquitin specific peptidase (USP)25, WW-domain-containing E3 ubiquitin protein ligase 1, immunoglobulin superfamily member 10, ARID1A, ubiquitin protein ligase E3 component $n$-recognin 3, and bromodomain adjacent to zinc finger domain $2 \mathrm{~B}$, after sequencing and analyzing the whole genomes of $27 \mathrm{HCC}$, including 25 with HBV- or HCV-associated HCC. Additionally, whole-genome sequencing analyses of HCCs demonstrated the influence of etiological backgrounds on mutation patterns and recurrent mutations in chromatin regulators [53]. The authors found that multiple chromatin regulators, including ARID1A, ARID1B, ARID2, lysine methyltransferase $2 \mathrm{~A}$, and lysine methyltransferase $2 \mathrm{C}$, were mutated in $~ 50 \%$ of the tumors, with clonal integration of the HBV genome in the TERT gene frequently detected.

Table 1. Representative driver-gene candidates in HCC.

\begin{tabular}{|c|c|c|c|}
\hline Gene Symbol & Gene Name & Pathways & References \\
\hline TERT & Telomerase reverse transcriptase & TERT & {$[52-56]$} \\
\hline CTNNB1 & Catenin $\beta 1$ & $\beta$-catenin & {$[52,53]$} \\
\hline TP53 & Tumor protein p53 & p53-RB & {$[52,53]$} \\
\hline ARID2 & AT-rich interaction domain 2 & Chromatin remodeling & [52] \\
\hline AXIN1 & Axin 1 & $\beta$-catenin & [52] \\
\hline TSC2 & TSC complex subunit 2 & PI3K-mTOR & [52] \\
\hline RB1 & Retinoblastoma 1 & p53-RB & [52] \\
\hline$A C V R 2 A$ & Activin A receptor type $2 \mathrm{~A}$ & SMAD & [52] \\
\hline BRD7 & Bromodomain containing 7 & Chromatin remodeling & {$[52]$} \\
\hline$C D K N 1 A$ & Cyclin-dependent kinase inhibitor 1A & $\beta$-catenin & [52] \\
\hline MEN1 & Menin 1 & (MEN1 syndrome) & [52] \\
\hline GALN11 & Polypeptide $N$-acetylgalactosaminyltransferase 11 & NOTCH & [52] \\
\hline FGF19 & Fibroblast growth factor 19 & $\beta$-catenin & [52] \\
\hline CCND1 & Cyclin D1 & p53-RB & [52] \\
\hline ARID1A & AT-rich interaction domain $1 \mathrm{~A}$ & Chromatin remodeling & {$[52-54,57,58]$} \\
\hline$C D K N 2 A$ & Cyclin-dependent kinase inhibitor 2A & $\mathrm{p} 53-\mathrm{RB}$ & [52] \\
\hline$C D K N 2 B$ & Cyclin-dependent kinase inhibitor $2 \mathrm{~B}$ & p53-RB & [52] \\
\hline RPS6KA3 & Ribosomal protein S6 kinase, $90 \mathrm{kDa}$, polypeptide 3 & p53-RB & [52] \\
\hline NFE2L2 & Nuclear factor, erythroid 2-like 2 & NRF2-KEAP1 & [52] \\
\hline NCOR1 & Nuclear receptor corepressor 1 & $\beta$-catenin/chromatin remodeling & [52] \\
\hline$A D H 1 B$ & Alcohol dehydrogenase $1 \mathrm{~B}, \beta$ polypeptide & & [52] \\
\hline SRCAP & Snf2-related CREB binding protein activator protein & Chromatin remodeling & [52] \\
\hline FCRL1 & Fc receptor like 1 & & [52] \\
\hline PTEN & Phosphatase and tensin homolog & PI3K-mTOR & [52] \\
\hline HNRNPA2B1 & Heterogeneous nuclear ribonucleoprotein A2/B1 & MAPK & [52] \\
\hline CYP2E1 & Cytochrome P450 family 2 subfamily E member 1 & & [52] \\
\hline$M A P 2 K 3$ & Mitogen-activated protein kinase 3 & MAPK & [52] \\
\hline TSC1 & Tuberous sclerosis 1 & mTOR & {$[52]$} \\
\hline TMEM99 & Transmembrane protein 99 & & [52] \\
\hline G6PC & Glucose-6-phosphatase, catalytic subunit & FoxO & [52] \\
\hline
\end{tabular}




\subsection{The $p 53-R B$ Pathway}

TP53 mutations have been reported in HCC in Japan and aflatoxin B1-induced HCC $[59,60]$. In HCC, the p53-RB pathway is altered in $72 \%$ of cases, with $68 \%$ of these a result of significantly altered genes [52]. Somatic mutations and copy number alterations in TP53, which plays a central role in apoptosis [61], are present in $31 \%$ and $37 \%$ of cases, respectively. Among the upstream genes targeted by p53, somatic mutations and copy number alterations in ATM are present in $4 \%$ and $6 \%$ of cases, respectively; those in RPS6KA3 are present in $4 \%$ and $5 \%$ of cases, respectively, and those in CDKN2A are present in $2 \%$ and $20 \%$ of cases, respectively. Among downstream genes targeted by p53, somatic mutations and copy number alterations in CDKN1A are present in $1 \%$ and $1 \%$ of cases, respectively; those in FBXW7 are present in $<1 \%$ and $16 \%$ of cases, respectively, and those in CCNE1, which suppress RB1 transcription and promote cell cycle progression, are present in $0 \%$ and $2 \%$ of cases, respectively. Among upstream genes targeted by RB, somatic mutations and copy number alterations in CCND1 are present in $0 \%$ and $8 \%$ of cases, respectively. Somatic mutations and copy number alterations in RB1, which inhibit cell cycle progression, are present in $4 \%$ and $20 \%$ of cases, respectively. Additionally, RB controls the levels of p21, which is associated with hepatocarcinogenesis [62]. Overall, $72 \%$ of HCC cases harbor alterations in component genes of either the p53 or RB pathway alone or the combined p53-RB pathway (Figure 2) [52].

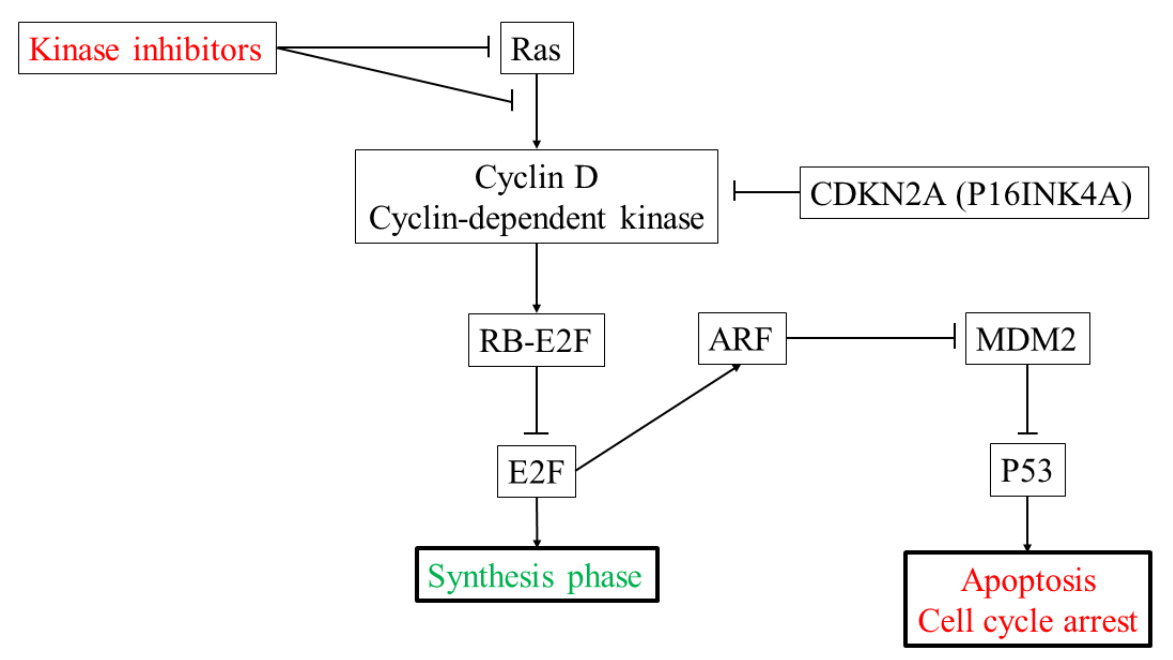

Figure 2. The p53-RB pathway in HCC.

\subsection{The $\beta$-catenin Pathway (WNT Pathway)}

In HCC, the $\beta$-catenin pathway is altered in $66 \%$ of cases, with $51 \%$ of these involving significantly altered genes [52]. Somatic mutations and copy number alterations in CTNNB1, which induce the expression of WNT target genes and transcription of CCND1 resulting in inhibited RB1 expression, are present in $31 \%$ and $<1 \%$ of cases, respectively [52]. Among the upstream genes targeted by $\beta$-catenin, somatic mutations and copy number alterations in NCOR1 are present in $2 \%$ and $29 \%$ of cases, respectively; those in FGF19 are present in $0 \%$ and $6 \%$ of cases, respectively; those in AXIN1 are present in $6 \%$ and $15 \%$ of cases, respectively; and those in APC are present in $2 \%$ and $4 \%$ of cases, respectively [52]. Overall, $66 \%$ of HCC cases harbored WNT-pathway-related alterations.

\subsection{Chromatin and Transcription Modulators}

In HCC, chromatin-remodeling pathways are altered in $67 \%$ of cases, with $41 \%$ of these involving significantly altered genes [52]. Among upstream genes associated with the nucleosome-remodeling pathway, somatic mutations and copy number alterations in ARID1B are present in $<1 \%$ and $15 \%$ of cases, respectively; those in ARID1A are present in $8 \%$ and $17 \%$ of cases, respectively; those in BRD7 are present in $2 \%$ and $16 \%$ of cases, respectively; those in ARID2 are present in $10 \%$ and $2 \%$ of 
cases, respectively; those in switch/sucrose non-fermentable (SWI/SNF)-related, matrix associated, actin-dependent regulator of chromatin (SMARC) subfamily C member 1 are present in $<1 \%$ and $4 \%$ of cases, respectively; those in SMARC subfamily B member 1 are present in $<1 \%$ and $6 \%$ of cases, respectively; those in SMARC subfamily A member 4 are present in $1 \%$ and $10 \%$, respectively; those in SMARC subfamily E member 1 are present in $<1 \%$ and $3 \%$ of cases, respectively; and those in SMARC subfamily A member 2 are present in $2 \%$ and $10 \%$ of cases, respectively [52]. Additionally, Li et al. reported that $18.2 \%$ of patients with HCV-associated HCC in the United States and Europe harbored ARID2-inactivation mutations [57]. Moreover, another study reported ARID1A mutation in 14 of $110(13 \%)$ HBV-associated HCC specimens [54]. ARID1A functions as the epigenetic regulation of hepatic lipid homeostasis, and its suppression leads to nonalcoholic fatty liver disease and nonalcoholic steatohepatitis (NASH) [58].

Among upstream genes associated with the histone-modification pathway, somatic mutations and copy number alterations in NCOR1 are present in $2 \%$ and $29 \%$ of cases, respectively; those in SRCAP are present in 3\% and 10\% of cases, respectively; those in SET domain bifurcated histone lysine methyltransferase 1 (SETDB1) are present in $2 \%$ and $<1 \%$ of cases, respectively; and those in lysine demethylase 6A (KDM6A) are present in $1 \%$ and $5 \%$ of cases, respectively [52]. Notably, the histone methyltransferase SETDB1 promotes HCC metastasis [63,64], and KDM6A is associated with the epithelial-mesenchymal transition in HCC [65].

\subsection{Other Pathways}

In HCC, the phosphoinositide 3-kinase (PI3K)-mTOR pathway is altered in $45 \%$ of cases, with $26 \%$ of these involving significantly altered genes [52]. Somatic mutations and copy number alterations of PI3KCA (encoding the p110 $\alpha$ subunit of PI3K) are present in $1 \%$ and $<1 \%$ of cases, respectively; those in neurofibromin 1 are present in $4 \%$ and 3\% of cases, respectively; those in PTEN are present in $1 \%$ and $10 \%$ of cases, respectively; those in inositol polyphosphate-4-phosphatase, type IIB, are present in $1 \%$ and $16 \%$ of cases, respectively; those in serine/threonine kinase 11 are present in $<1 \%$ and $11 \%$ of cases, respectively; those in TSC 1 are present in $2 \%$ and $8 \%$ of cases, respectively; and those in TSC2 are present in 5\% and 14\% of cases, respectively [52]. TSC1 and TSC2 suppress mTOR expression, which promotes HCC proliferation and survival. In sorafenib-treated patients with HCC, oncogenic PI3K-mTOR-pathway alterations are associated with lower disease-control rates and decreased median progression-free survival and overall survival [66].

In HCC, the nuclear factor (erythroid-derived 2)-like 2 (NRF2)-kelch-like ECH-associated protein 1 (KEAP1) pathway is altered in $19 \%$ of cases, with $5 \%$ of these involving significantly altered genes [52]. The NRF2-KEAP1 pathway is associated with an oxidative-stress response, and persistent activation of NRF2 through the accumulation of p62 is involved in HCC development [67-69].

There are many protein-coding genes recurrently mutated at a frequency of $<5 \%$ in HCC $[55,70]$, whereas HBV integrations and frequent noncoding mutations in the TERT promoter represent prominent examples of noncoding mutations in HCC [52-55]. Nault et al. [56] identified frequent somatic mutations resulting in the activation of the TERT promoter in HCC (59\%), cirrhotic preneoplastic macronodules $(25 \%)$, and hepatocellular adenomas with malignant transformation in HCC (44\%). Moreover, TERT-promoter mutation represents the most frequent genetic alteration in HCC arising from the cirrhotic or non-cirrhotic liver [56], resulting in reportedly enhanced TERT activity in HCC [71].

\section{Molecular Mechanisms of HBV-Associated HCC}

\subsection{HBV Genome Integration Promotes HCC}

The discovery that HBV integrates into host chromosomes calls into question whether HBV genome integration interacts with the activation of oncogenic processes in HCC [72]. Tokino et al. [72] could not detect specific HBV genome-integration sites in chromosomes. About half of HBV DNA-cell 
DNA junctions are located within the so-called cohesive end region that lies between two 11-bp direct repeats (DR1 and DR2) in the HBV genome where transcription and replication of the genome are initiated. All of the integrated HBV genomes were defective in at least one site around the cohesive end region, particularly within the HBx gene [73]. Additionally, Imazeki et al. [74] detected integrated HBV DNA in all nine HBsAg-seropositive HCCs and three of 25 (12\%) HBsAg-seronegative HCCs in Japan. An analysis of breakpoints within the integration region showed that $40 \%$ of breakpoints were near the 1800th nucleotide of the HBV genome, which contains an enhancer, an HBx gene, and core promoters of the HBV genome [75].

TERT is located on chromosome $5 p$, which is one of the most common targets for amplification in non-small cell lung cancer [76] and is reportedly directly associated with HBV genome integration [77]. Recent data from whole-genome sequencing supports this observation and confirmed the frequent observation of HBV genome integration in the TERT locus in a high clonal proportion [52-56].

HBx expression might play a role in hepatocarcinogenesis by interfering with telomerase activity during hepatocyte proliferation [78], which is supported by breakpoint analysis of the HBV genome [75]. HBx functions as a transcriptional activator and suppressor and has effects on hepatocellular apoptosis $[79,80]$. HBx proteins may upregulate the transcriptional activation of human telomerase transcriptase [81]. Cis-activation of human TERT mRNA by HBx gene may also be the mechanism in hepatocarcinogenesis [82].

Therefore, $\mathrm{HBV}$ genome integration into host genomes is a mechanism involved in HCC associated with HBV infection. Moreover, whole-genome sequencing demonstrated that the integration of HBV DNA into the host hepatocyte genome can be detected in $80 \%$ to $90 \%$ of HCC and in $~ 30 \%$ of non-HCC liver tissue adjacent to HCC [83], and that this integration appears prior to the occurrence of HCC [75]. Thus, it is possible that occult HBV infection may also accelerate hepatocarcinogenesis in HBsAg-negative patients to some extent [84].

\subsection{Inflammation Promotes HBV-Associated HCC}

In general, a high number of HBV-DNA integrations randomly distributed among chromosomes has been detected in HBV-infected liver [85]. Chronic HBV infection progresses through multiple phases, including immune tolerance, immune activation, immune control, and, in a subset of patients who achieve immune control and immune reactivation [86]. Immune-mediated liver injury is often associated with elevated ALT levels, and elevations in tumor necrosis factor- $\alpha$ (TNF- $\alpha$ ) and interleukin (IL)-1 $\beta$ levels are often observed in the sera of HBV-infected patients [87]. Additionally, long-lasting hepatic inflammation caused by host immune responses during chronic HBV infection can promote liver fibrosis, cirrhosis and HCC progression due to accelerated hepatocyte turnover rates and the accumulation of mutations [88].

\subsection{Epigenetic Mechanisms Involved in HBV-Associated HCC}

Epigenetic mechanisms play a role in HBV-associated hepatocarcinogenesis. MicroRNAs (miRs) are endogenous noncoding RNAs (18-22 nucleotides in length) that posttranscriptionally regulate the expression of target genes. miRs bind to the $3^{\prime}$-untranslated region (UTR) of target mRNA, thereby inhibiting translation [89].

Several miRNAs involved in the Toll-like receptor (TLR) signaling pathway play a critical role in innate immunity against HBV infection [89]. For example, miR-145 and miR-148a target TLR3, miR-200b, miR-200c, miR148a, miR-455, and let-7-family members target TLR4, let-7b and miR-155 target TLR7, and miR-148a targets TLR9, and all of which are involved in HBV infection [89,90]. HBV might influence miR expression and induce inflammatory cytokine production [91]. Previous reports indicated that some hepatic miRs are involved in the pathogenesis of HBV-associated HCC [92-142], with certain serum miRs involved in HBV-associated HCC also potentially useful as biomarkers (Table 2). 
Table 2. Hepatic and serum miRs involved in HBV-associated HCC.

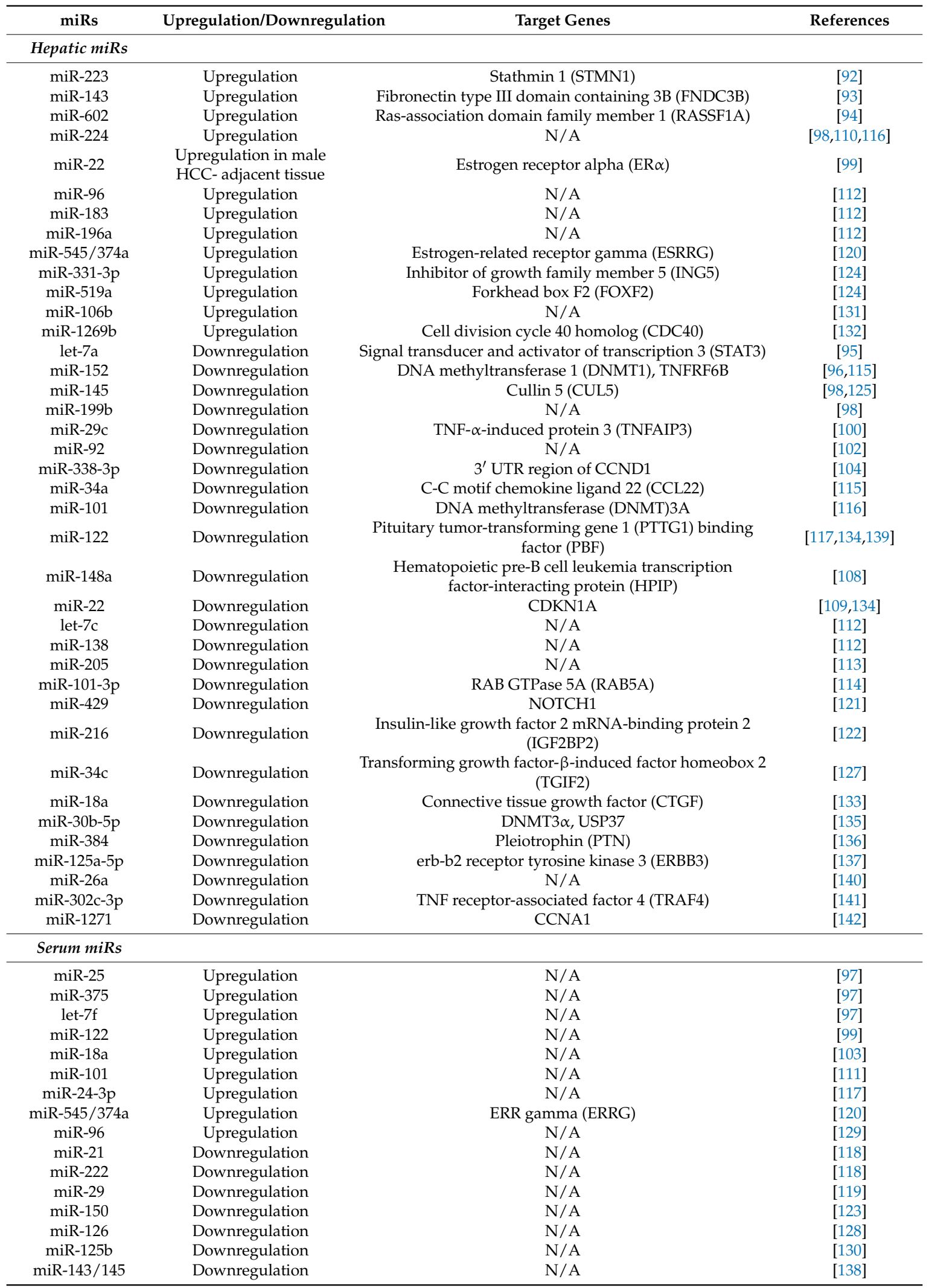

Other noncoding RNAs, such as long noncoding RNAs (lncRNAs) and circular RNA (circRNA), are also involved in the pathogenesis of HBV-associated HCC [143-145]. Functional studies reveal that lncRNAs (100-300 kb) contribute to the onset and progression of HBV-related HCC [143], and circRNAs, 
which form covalently closed continuous loops by means of unique non-canonical 'head-to-tail' splicing in the absence of free $3^{\prime}$ or $5^{\prime}$ ends, might promote the development of HBV-associated HCC [144,145].

Epigenetic silencing of genes, such as methylation of promoter regions, also regulates gene expression in HBV-associated HCC and could potentially serve as a diagnostic and prognostic marker of the disease $[146,147]$. Additionally, HBV can cause epigenetic changes by altering the methylation state of cellular DNA, the posttranslational modification of histones, and miR expression [146,148], all of which are also critical for the pathogenesis of HBV-associated HCC.

\subsection{Roles of HBV-encoded Proteins}

HBV is a partially double-stranded DNA virus (genome length: $3200 \mathrm{bp}$ ) and a member of the Orthohepadnavirus genus and the Hepadnaviridae family [149]. The HBV genome encodes at least four proteins [HBsAg, a core protein (splice variant: HBeAg), a DNA polymerase, and the HBx protein] that are translated from mRNAs transcribed from HBV covalently closed circular DNA and/or from HBV genome sequences integrated into the host genome [150]. Viral protein translation is initiated through binding of the PreS2 domain of HBV surface antigens to protein kinase $C$ (PKC) $\alpha / \beta$, which triggers PKC-dependent activation of Raf-1 proto-oncogene serine/threonine kinase (RAF-1)/MAP2K signaling and transcription factors, such as activator protein-1 (AP-1) and nuclear factor kappaB (NF-kB), resulting in the increased proliferation of hepatocytes [151]. PreS2-mediated activity subsequently upregulates the expression of the transcriptional coactivator with PDZ-binding motif by repressing miRNA-338-3p, which promotes HCC proliferation and migration [152]. Moreover, a previous study showed that a truncated mutant of HBsAg increases HBV-related tumorigenesis in a mechanism potentially associated with the downregulated expression of tumor growth factor (TGF)BI associated with the TGF $\beta$-SMAD pathway [153]. Furthermore, HBsAg enhances the IL-6-STAT3 pathway, thereby increasing the HBsAg-mediated malignant potential of HBV-associated HCC [154].

The HBV core protein enhances cytokine production [155], and HBeAg is reportedly associated with the host immune response and cytokine production [156-158], both of which play roles in HBV-associated HCC.

Numerous studies reported an association between the HBx protein and hepatocarcinogenesis [159-170]. Integrated HBV DNA harbors the conserved sequences for genes encoding the core protein, surface antigens, and HBx along with their respective promoter sequences $[159,160]$, suggesting that HBx is important for hepatocarcinogenesis. HBx represents a transactivating factor [161], and transgenic mice expressing HBx develop HCC [162]. HBx transactivates binding sites for the transcription factors AP-1 and NF-kB [163], activates the p53-RB [164,165] and $\beta$-catenin [164-170] pathways, and is involved in chromatin remodeling [171-173] and transcriptional modulation in hepatocarcinogenesis [174].

Overexpression of the HBV polymerase due to core-gene deletion enhances HCC-cell growth by inhibiting miR-100 [175]. A previous study showed that transgenic mice expressing the reverse-transcriptase domain of HBV polymerase in their livers developed early cirrhosis with steatosis by 18 months of age, with 10\% subsequently developing HCC [176].

\section{Molecular Mechanisms of HCV-Associated HCC}

\subsection{Inflammation Promotes HCV-Associated HCC}

Cytokines reflect the degree of inflammation in the liver of patients with chronic hepatitis $\mathrm{C}$, with this production possibly related to HCC development [177]. Takano et al. [1] prospectively investigated the incidence of HCC in 124 cases with HCV infection, finding that HCC occurred in 13 cases that included 12 cirrhotic livers and only 1 non-cirrhotic liver and suggesting that most HCC occurs in advanced liver diseases in HCV-infected individuals [178]. Because hepatic inflammation plays a role in the development of advanced liver diseases, inflammation is an important aspect in the development of HCC associated with chronic HCV infection. 


\subsection{Epigenetic Mechanisms Involved in HCV-Associated HCC}

Epigenetic mechanisms also play a role in $\mathrm{HCV}$-associated hepatocarcinogenesis. Previous studies reported the involvement of specific hepatic and serum miRs in the pathogenesis of HCV-associated HCC [179-196], with some of the serum miRs representing potentially useful biomarkers of the disease (Table 3). Notably, the number of reports of miRs involved in HCV-associated HCC is smaller than that related to HBV-associated HCC (Table 2).

Table 3. Hepatic and serum miRs involved in HCV-associated HCC.

\begin{tabular}{cccc}
\hline miRs & Upregulation/Downregulation & Target Genes & References \\
\hline Hepatic miRs & & & \\
\hline miR-193b & Upregulation & STMN1 & {$[179]$} \\
miR-155 & Upregulation & N/A & {$[180]$} \\
miR-122 & Upregulation & Cyclin G1 & {$[181,182,186]$} \\
miR-373 & Upregulation & Wee1 & {$[195]$} \\
miR-24 & Downregulation & N/A & {$[183]$} \\
miR-27a & Downregulation & $\mathrm{N} / \mathrm{A}$ & {$[183]$} \\
miR-198 & Downregulation & $\mathrm{N} / \mathrm{A}$ & {$[184]$} \\
miR-152 & Downregulation & $\mathrm{N} / \mathrm{A}$ & {$[186]$} \\
miR-181c & Downregulation & Homeobox A1 & {$[187]$} \\
miR-431 & Downregulation & $\mathrm{N} / \mathrm{A}$ & {$[189]$} \\
miR-138 & Downregulation & TERT & {$[192]$} \\
\hline Serum miRs & & & \\
\hline miR-150 & Upregulation & $\mathrm{N} / \mathrm{A}$ & {$[191]$} \\
miR-221 & Upregulation & $\mathrm{N} / \mathrm{A}$ & {$[193]$} \\
miR-101-1 & Upregulation & $\mathrm{N} / \mathrm{A}$ & {$[194]$} \\
miR-27a & Upregulation & N/A & {$[188]$} \\
miR-221 & Downregulation & Suppressor of cytokine & {$[190]$} \\
miR-16 & Downregulation & signaling (SOCS)1 and SOCS3 & {$[194]$} \\
miR-34a & Downregulation & Heat-shock protein 70 & \\
\hline
\end{tabular}

Previous studies reported that lncRNAs are involved in the pathogenesis of HBV-associated HCC [143-145], with functional studies revealing that these lncRNAs contribute also to the onset and progression of HCV-related HCC [195,197]. Zhang et al. [198] reported LINC01419 transcripts expressed at higher levels in early stage HCC as compared with levels observed in dysplastic tissue. Moreover, this study also reported increased and decreased levels of AK021443 and AF070632 in advanced HCC, respectively, and that LINC01419 and AK021443 regulated the expression of genes associated with cell cycle progression, whereas AF070632 was associated with cofactor binding, oxidation-reduction activity and carboxylic acid catabolic processes [198].

Upregulated lncRNAs associated with urothelial carcinoma associated-1 (lncRNA-UCA1) and WD-repeat-containing antisense to TP53 (lncRNA-Wrap53) potentially serve as novel serum biomarkers for HCC diagnosis and prognosis [199]. Additionally, the lncRNA associated with activated by TGF $\beta$ (lncRNA-ATB) is a key regulator of TGF $\beta$ signaling and is positively correlated with the development of liver cirrhosis and HCC-specific vascular invasion [200]. Moreover, lncRNA-ATB might represent a novel diagnostic biomarker and potential therapeutic target for HCV-related hepatic fibrosis [200]. A previous study showed that HCV infection upregulates the expression of miR-373 and Wee1-like protein kinase (WEE1), a pivotal player in the G2/M transition in the cell cycle (although WEE1 is a direct target of miR-373). This study also showed that miR-373 forms a complex with the LINC00657, resulting in release of their common target, WEE1, in HCV-infected cells, and the promotion of uncontrolled cell growth [195]. Another study reported that hypermethylation of promoter regions suppressed mRNA expression, which played a role in the progression of HCV-associated HCC [201]. 


\subsection{Roles of HCV-coding Proteins}

We previously reported the roles for HCV-coding proteins in hepatocarcinogenesis [178], with the HCV core proteins and NS5A reportedly playing important roles in HCC development [202-206]. HCV-infected patients showed a higher prevalence of diabetes mellitus and insulin resistance (IR) relative to those with HBV infection [207]. IR measured using a homeostasis model assessment of IR (HOMA-IR) is significantly associated with HCC development in patients with or without chronic HCV infection. Moreover, patients with NASH, which is associated with elevated HOMA-IR, have an increased risk of liver fibrosis, cirrhosis, and HCC [208,209].

A previous study showed that the HCV core protein downregulates insulin receptor substrate (IRS) 1 and IRS2 by upregulating SOCS3 levels [210]. Moreover, cross-talk between the HCV core protein and molecules regulating insulin signaling might affect HCV-associated hepatocarcinogenesis [210-214]. Insulin-like growth factors initiate tyrosyl phosphorylation of IRS1 and activate multiple signaling pathways essential for liver growth and HCC [215], with the activation of IRS1-mediated signaling potentially contributing to hepatic oncogenesis.

CCAAT/enhancer-binding protein (C/EBP $\beta)$ and HCV NS5A might be essential components promoting increased gluconeogenesis associated with HCV infection [216]. Previous studies reported the involvement of HCV NS5A in enhanced gluconeogenic gene expression associated with impaired insulin signaling [217,218].

Sphere-forming hepatocytes express several cancer stem-like cell (CSC) markers, including c-Kit. Previous studies showed that the HCV core protein significantly upregulates c-Kit expression at the transcriptional level, and that HCV infection potentiates CSC generation $[219,220]$. Additionally, a Western diet high in cholesterol and saturated fat (HCFD) in combination with the translation of HCV NS5A stimulates TLR4-Nanog homeobox (NANOG) and leptin receptor-phosphorylated STAT3 signaling, resulting in liver tumorigenesis through an exaggerated mesenchymal phenotype involving prominent Twist1-expressing tumor-initiating stem-like cells expressing NANOG [221].

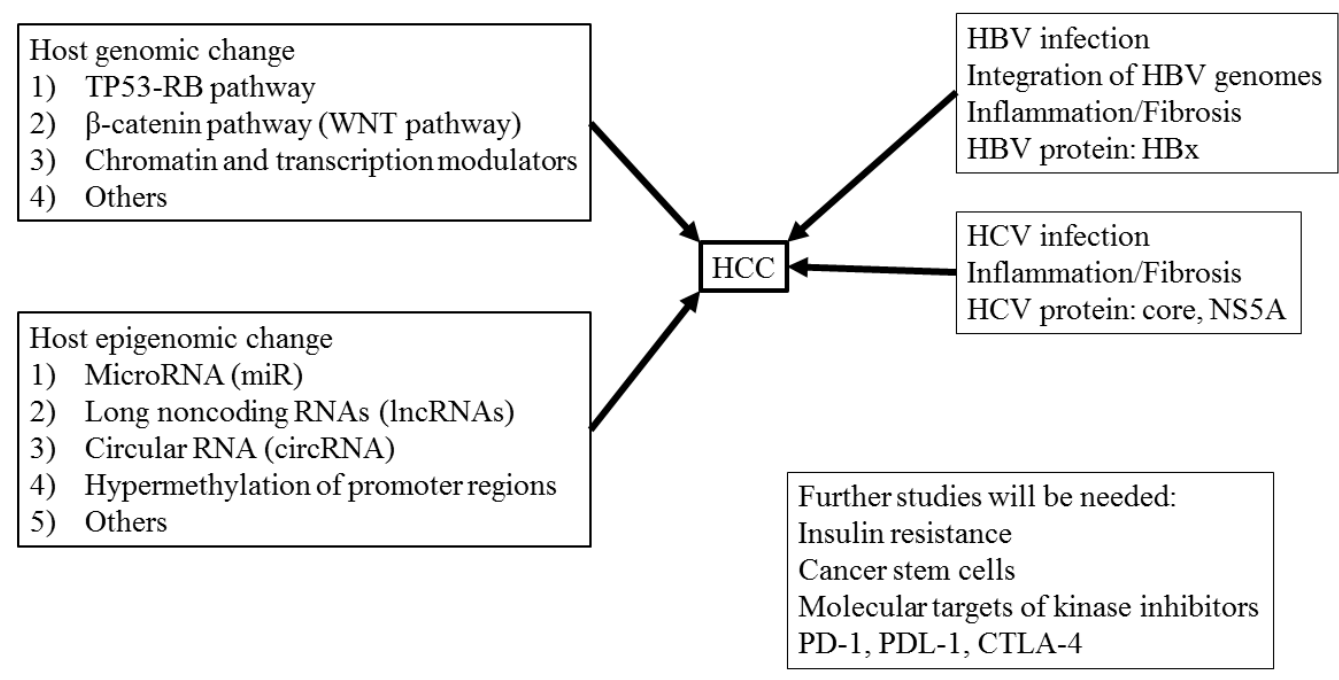

Figure 3. Molecular mechanisms of liver cirrhosis and its progression to HCC.

\section{HCC-specific Molecular Mechanisms from a Therapeutic Point of View}

Sorafenib, regorafenib and lenvatinib are approved therapies as oral molecular-targeting drugs for advanced stages of HCC [3-6]. Sorafenib is an oral serine/threonine kinase inhibitor targeting the extracellular-signaling-regulated kinase/MAPK pathway, vascular endothelial growth factor receptor (VEGFR), platelet-derived growth factor receptor (PDGFR), and epithelial growth factor receptor (EGFR). Additionally, it acts as a tyrosine kinase inhibitor targeting VEGFR1, VEGFR2, VEGFR3, 
PDGFR $\beta$, ret proto-oncogene (RET), and fms-related tyrosine kinase 3, resulting in the inhibition of tumor proliferation [222].

Regorafenib is an oral multiple kinase inhibitor of VEGFR1, VEGFR2, VEGFR3, TEK receptor tyrosine kinase, PDGFR $\beta$, fibroblast growth factor receptor (FGFR), proto-oncogene receptor tyrosine kinase (KIT), RET, RAF-1, and B-RAF. Lenvatinib is an oral tyrosine kinase inhibitor targeting VEGFR1/2/3, FGFR1/2/3/4, PDGFR $\alpha$, KIT, and RET to inhibit tumor angiogenesis and growth [222]. Therefore, sorafenib, regorafenib, and lenvatinib represent multiple kinase inhibitors that do not suppress a specific molecule, thereby restricting their use only in patients with advanced HCC and well-compensated liver function.

Nivolumab, pembrolizumab and tislelizumab are anti-programmed death-1 (PD-1) antibodies. The immune-checkpoint molecule PD-1 is a receptor that negatively regulates immune responses [222,223] via binding of its representative ligands PD-ligand (PD-L)1 and PD-L2. Inhibition of this pathway can eliminate tumors by recovering their immunosuppressive effects and restoring innate immune activity [222,224]. Cytotoxic T lymphocyte-associated antigen-4 (CTLA-4) is another counterreceptor for the B7 family of costimulatory molecules and a negative regulator of $\mathrm{T}$ cell activation. A blockade of the inhibitory effects of CTLA-4 is supposed to enhance immune responses against tumor cells [225] and also represents a type of immune checkpoint. The blockade of such immune checkpoints represents a promising therapeutic option for HCC; therefore, further studies are needed to determine other immune checkpoints, as well as potential targets of kinase inhibitors related to liver cirrhosis to HCC.

\section{Conclusions}

This review describes the molecular mechanisms of liver cirrhosis and its progression to HCC (Figure 3). Recent progress in next-generation sequencing has revealed several HCC-specific driver-gene candidates. Additionally, 70\% of HCC cases are caused by HBV and/or HCV infection. Although nucleos(t)ide analogs and direct-acting antivirals can control HBV and HCV replication, HCC occurrence is occasionally observed [49-51], and better biomarkers for early detection of HCC are needed. Furthermore, genetic and epigenetic factors, such as miRs, are involved in liver cirrhosis and its progression to HCC. Despite significant advances, additional studies are required to elucidate other molecular mechanisms, including immune checkpoints and molecular targets of kinase inhibitors associated with liver cirrhosis and its progression to HCC.

Author Contributions: Writing-Original Draft Preparation, T.K.; Writing-Review \& Editing, T.G., Y.H., M.M.; Supervision, M.O.

Funding: This work was partly supported by JSPS KAKENHI GRANT Number 17K09404 (to T.K.).

Conflicts of Interest: The other authors declare no conflict of interest.

\section{References}

1. Takano, S.; Yokosuka, O.; Imazeki, F.; Tagawa, M.; Omata, M. Incidence of hepatocellular carcinoma in chronic hepatitis B and C: A prospective study of 251 patients. Hepatology 1995, 21, 650-655. [CrossRef] [PubMed]

2. Takayama, T.; Makuuchi, M. Segmental liver resections, present and future-caudate lobe resection for liver tumours. Hepatogastroenterology 1998, 45, 20-23.

3. Llovet, J.M.; Ricci, S.; Mazzaferro, V.; Hilgard, P.; Gane, E.; Blanc, J.F.; de Oliveira, A.C.; Santoro, A.; Raoul, J.L.; Forner, A.; et al. Sorafenib in advanced hepatocellular carcinoma. N. Engl. J. Med. 2008, 359, 378-390. [CrossRef] [PubMed]

4. Cheng, A.L.; Kang, Y.K.; Chen, Z.; Tsao, C.J.; Qin, S.; Kim, J.S.; Luo, R.; Feng, J.; Ye, S.; Yang, T.S.; et al. Efficacy and safety of sorafenib in patients in the Asia-Pacific region with advanced hepatocellular carcinoma: A phase III randomised, double-blind, placebo-controlled trial. Lancet Oncol. 2009, 10, 25-34. [CrossRef] 
5. Bruix, J.; Qin, S.; Merle, P.; Granito, A.; Huang, Y.H.; Bodoky, G.; Pracht, M.; Yokosuka, O.; Rosmorduc, O.; Breder, V.; et al. Regorafenib for patients with hepatocellular carcinoma who progressed on sorafenib treatment (RESORCE): A randomised, double-blind, placebo-controlled, phase 3 trial. Lancet 2017, 389, 56-66. [CrossRef]

6. Kudo, M.; Finn, R.S.; Qin, S.; Han, K.H.; Ikeda, K.; Piscaglia, F.; Baron, A.; Park, J.W.; Han, G.; Jassem, J.; et al. Lenvatinib versus sorafenib in first-line treatment of patients with unresectable hepatocellular carcinoma: A randomised phase 3 non-inferiority trial. Lancet 2018, 391, 1163-1173. [CrossRef]

7. Schachter, J.; Ribas, A.; Long, G.V.; Arance, A.; Grob, J.J.; Mortier, L.; Daud, A.; Carlino, M.S.; McNeil, C.; Lotem, M.; et al. Pembrolizumab versus ipilimumab for advanced melanoma: Final overall survival results of a multicentre, randomised, open-label phase 3 study (KEYNOTE-006). Lancet 2017, 390, 1853-1862. [CrossRef]

8. Bruix, J.; Reig, M.; Sherman, M. Evidence-Based Diagnosis, Staging, and Treatment of Patients With Hepatocellular Carcinoma. Gastroenterology 2016, 150, 835-853. [CrossRef]

9. Obi, S.; Yoshida, H.; Toune, R.; Unuma, T.; Kanda, M.; Sato, S.; Tateishi, R.; Teratani, T.; Shiina, S.; Omata, M. Combination therapy of intraarterial 5-fluorouracil and systemic interferon-alpha for advanced hepatocellular carcinoma with portal venous invasion. Cancer 2006, 106, 1990-1997. [CrossRef] [PubMed]

10. Kanda, T.; Takahashi, K.; Nakamura, M.; Nakamoto, S.; Wu, S.; Haga, Y.; Sasaki, R.; Jiang, X.; Yokosuka, O. Androgen Receptor Could Be a Potential Therapeutic Target in Patients with Advanced Hepatocellular Carcinoma. Cancers 2017, 9, 43. [CrossRef] [PubMed]

11. Fattovich, G.; Stroffolini, T.; Zagni, I.; Donato, F. Hepatocellular carcinoma in cirrhosis: Incidence and risk factors. Gastroenterology 2004, 127 (Suppl. 1), S35-S50. [CrossRef]

12. Bataller, R.; Brenner, D.A. Liver fibrosis. J. Clin. Investig. 2005, 115, 209-218. [CrossRef] [PubMed]

13. Patel, K.; Bedossa, P.; Castera, L. Diagnosis of liver fibrosis: Present and future. Semin. Liver Dis. 2015, 35, 166-183. [CrossRef]

14. Xu, L.; Hui, A.Y.; Albanis, E.; Arthur, M.J.; O’Byrne, S.M.; Blaner, W.S.; Mukherjee, P.; Friedman, S.L.; Eng, F.J. Human hepatic stellate cell lines, LX-1 and LX-2: New tools for analysis of hepatic fibrosis. Gut 2005, 54, 142-151. [CrossRef]

15. Okuda, K.; Nakashima, T.; Kojiro, M.; Kondo, Y.; Wada, K. Hepatocellular carcinoma without cirrhosis in Japanese patients. Gastroenterology 1989, 97, 140-146. [CrossRef]

16. Clouston, A.D.; Powell, E.E.; Walsh, M.J.; Richardson, M.M.; Demetris, A.J.; Jonsson, J.R. Fibrosis correlates with a ductular reaction in hepatitis C: Roles of impaired replication, progenitor cells and steatosis. Hepatology 2005, 41, 809-818. [CrossRef]

17. Lozano, R.; Naghavi, M.; Foreman, K.; Lim, S.; Shibuya, K.; Aboyans, V.; Abraham, J.; Adair, T.; Aggarwal, R.; Ahn, S.Y.; et al. Global and regional mortality from 235 causes of death for 20 age groups in 1990 and 2010: A systematic analysis for the Global Burden of Disease Study 2010. Lancet 2012, 380, 2095-2128. [CrossRef]

18. Liaw, Y.F.; Tai, D.I.; Chu, C.M.; Chen, T.J. The development of cirrhosis in patients with chronic type B hepatitis: A prospective study. Hepatology 1988, 8, 493-496. [CrossRef]

19. Fattovich, G.; Brollo, L.; Giustina, G.; Noventa, F.; Pontisso, P.; Alberti, A.; Realdi, G.; Ruol, A. Natural history and prognostic factors for chronic hepatitis type B. Gut 1991, 32, 294-298. [CrossRef] [PubMed]

20. Sumi, H.; Yokosuka, O.; Seki, N.; Arai, M.; Imazeki, F.; Kurihara, T.; Kanda, T.; Fukai, K.; Kato, M.; Saisho, H. Influence of hepatitis B virus genotypes on the progression of chronic type B liver disease. Hepatology 2003, 37, 19-26. [CrossRef]

21. Liaw, Y.F.; Chen, Y.C.; Sheen, I.S.; Chien, R.N.; Yeh, C.T.; Chu, C.M. Impact of acute hepatitis C virus superinfection in patients with chronic hepatitis B virus infection. Gastroenterology 2004, 126, 1024-1029. [CrossRef]

22. Lacombe, K.; Massari, V.; Girard, P.M.; Serfaty, L.; Gozlan, J.; Pialoux, G.; Mialhes, P.; Molina, J.M.; Lascoux-Combe, C.; Wendum, D.; et al. Major role of hepatitis B genotypes in liver fibrosis during coinfection with HIV. AIDS 2006, 20, 419-427. [CrossRef]

23. Stroffolini, T.; Esvan, R.; Biliotti, E.; Sagnelli, E.; Gaeta, G.B.; Almasio, P.L. Gender differences in chronic HBsAg carriers in Italy: Evidence for the independent role of male sex in severity of liver disease. J. Med. Virol. 2015, 87, 1899-1903. [CrossRef] 
24. Al-Qahtani, A.; Khalak, H.G.; Alkuraya, F.S.; Al-hamoudi, W.; Alswat, K.; Al Balwi, M.A.; Al Abdulkareem, I.; Sanai, F.M.; Abdo, A.A. Genome-wide association study of chronic hepatitis B virus infection reveals a novel candidate risk allele on 11q22.3. J. Med. Genet. 2013, 50, 725-732. [CrossRef] [PubMed]

25. Chang, S.W.; Fann, C.S.; Su, W.H.; Wang, Y.C.; Weng, C.C.; Yu, C.J.; Hsu, C.L.; Hsieh, A.R.; Chien, R.N.; Chu, C.M.; et al. A genome-wide association study on chronic HBV infection and its clinical progression in male Han-Taiwanese. PLoS ONE 2014, 9, e99724. [CrossRef]

26. Chu, C.M.; Liaw, Y.F. Hepatitis B virus-related cirrhosis: Natural history and treatment. Semin. Liver Dis. 2006, 26, 142-152. [CrossRef]

27. Tawada, A.; Kanda, T.; Imazeki, F.; Yokosuka, O. Prevention of hepatitis B virus-associated liver diseases by antiviral therapy. Hepatol. Int. 2016, 10, 574-593. [CrossRef]

28. World Health Organization. Global Hepatitis Report. 2017. Available online: www.who.int/hepatitis/ publications/global-hepatitis-report2017/en/ (accessed on 27 December 2018).

29. Yang, Y.H.; Chen, W.C.; Tsan, Y.T.; Chen, M.J.; Shih, W.T.; Tsai, Y.H.; Chen, P.C. Statin use and the risk of cirrhosis development in patients with hepatitis C virus infection. J. Hepatol. 2015, 63, 1111-1117. [CrossRef]

30. Forns, X.; Ampurdanès, S.; Sanchez-Tapias, J.M.; Guilera, M.; Sans, M.; Sánchez-Fueyo, A.; Quintó, L.; Joya, P.; Bruguera, M.; Rodés, J. Long-term follow-up of chronic hepatitis C in patients diagnosed at a tertiary-care center. J. Hepatol. 2001, 35, 265-271. [CrossRef]

31. Westin, J.; Nordlinder, H.; Lagging, M.; Norkrans, G.; Wejstål, R. Steatosis accelerates fibrosis development over time in hepatitis C virus genotype 3 infected patients. J. Hepatol. 2002, 37, 837-842. [CrossRef]

32. Rubbia-Brandt, L.; Fabris, P.; Paganin, S.; Leandro, G.; Male, P.J.; Giostra, E.; Carlotto, A.; Bozzola, L.; Smedile, A.; Negro, F. Steatosis affects chronic hepatitis C progression in a genotype specific way. Gut 2004, 53, 406-412. [CrossRef]

33. Locasciulli, A.; Testa, M.; Pontisso, P.; Benvegnù, L.; Fraschini, D.; Corbetta, A.; Noventa, F.; Masera, G.; Alberti, A. Prevalence and natural history of hepatitis $C$ infection in patients cured of childhood leukemia. Blood 1997, 90, 4628-4633. [PubMed]

34. Kenny-Walsh, E. Clinical outcomes after hpatitis $\mathrm{C}$ infection from contaminated anti-D immune globulin. Irish Hepatology Research Group. N. Engl. J. Med. 1999, 340, 1228-1233. [CrossRef]

35. Poynard, T.; Bedossa, P.; Opolon, P. Natural history of liver fibrosis progression in patients with chronic hepatitis C. The OBSVIRC, METAVIR, CLINIVIR, and DOSVIRC groups. Lancet 1997, 349, 825-832. [CrossRef]

36. Poynard, T.; Ratziu, V.; Charlotte, F.; Goodman, Z.; McHutchison, J.; Albrecht, J. Rates and risk factors of liver fibrosis progression in patients with chronic hepatitis c. J. Hepatol. 2001, 34, 730-739. [CrossRef]

37. Shiffman, M.L. Natural history and risk factors for progression of hepatitis $C$ virus disease and development of hepatocellular cancer before liver transplantation. Liver Transpl. 2003, 9, S14-S20. [CrossRef] [PubMed]

38. Fuster, D.; Planas, R.; Muga, R.; Ballesteros, A.L.; Santos, J.; Tor, J.; Sirera, G.; Guardiola, H.; Salas, A.; Cabré, E.; et al. Advanced liver fibrosis in HIV/HCV-coinfected patients on antiretroviral therapy. AIDS Res. Hum. Retrovir. 2004, 20, 1293-1297. [CrossRef] [PubMed]

39. Ribes, J.; Clèries, R.; Rubió, A.; Hernández, J.M.; Mazzara, R.; Madoz, P.; Casanovas, T.; Casanova, A.; Gallen, M.; Rodríguez, C.; et al. Cofactors associated with liver disease mortality in an HBsAg-positive Mediterranean cohort: 20 years of follow-up. Int. J. Cancer 2006, 119, 687-694. [CrossRef]

40. Wilson, L.E.; Torbenson, M.; Astemborski, J.; Faruki, H.; Spoler, C.; Rai, R.; Mehta, S.; Kirk, G.D.; Nelson, K.; Afdhal, N.; et al. Progression of liver fibrosis among injection drug users with chronic hepatitis C. Hepatology 2006, 43, 788-795. [CrossRef]

41. Petta, S.; Cammà, C.; Di Marco, V.; Alessi, N.; Cabibi, D.; Caldarella, R.; Licata, A.; Massenti, F.; Tarantino, G.; Marchesini, G.; et al. Insulin resistance and diabetes increase fibrosis in the liver of patients with genotype 1 HCV infection. Am. J. Gastroenterol. 2008, 103, 1136-1144. [CrossRef]

42. Dyal, H.K.; Aguilar, M.; Bhuket, T.; Liu, B.; Holt, E.W.; Torres, S.; Cheung, R.; Wong, R.J. Concurrent Obesity, Diabetes, and Steatosis Increase Risk of Advanced Fibrosis Among HCV Patients: A Systematic Review. Dig. Dis. Sci. 2015, 60, 2813-2824. [CrossRef] [PubMed]

43. Shiratori, Y.; Imazeki, F.; Moriyama, M.; Yano, M.; Arakawa, Y.; Yokosuka, O.; Kuroki, T.; Nishiguchi, S.; Sata, M.; Yamada, G.; et al. Histologic improvement of fibrosis in patients with hepatitis $C$ who have sustained response to interferon therapy. Ann. Intern. Med. 2000, 132, 517-524. [CrossRef] 
44. Caporaso, N.; Romano, M.; Marmo, R.; de Sio, I.; Morisco, F.; Minerva, A.; Coltorti, M. Hepatitis C virus infection is an additive risk factor for development of hepatocellular carcinoma in patients with cirrhosis. J. Hepatol. 1991, 12, 367-371. [CrossRef]

45. Benvegnù, L.; Fattovich, G.; Noventa, F.; Tremolada, F.; Chemello, L.; Cecchetto, A.; Alberti, A. Concurrent hepatitis $B$ and $C$ virus infection and risk of hepatocellular carcinoma in cirrhosis. A prospective study. Cancer 1994, 74, 2442-2448. [CrossRef]

46. Ishikawa, T.; Ichida, T.; Yamagiwa, S.; Sugahara, S.; Uehara, K.; Okoshi, S.; Asakura, H. High viral loads, serum alanine aminotransferase and gender are predictive factors for the development of hepatocellular carcinoma from viral compensated liver cirrhosis. J. Gastroenterol. Hepatol. 2001, 16, 1274-1281. [CrossRef]

47. Ohata, K.; Hamasaki, K.; Toriyama, K.; Matsumoto, K.; Saeki, A.; Yanagi, K.; Abiru, S.; Nakagawa, Y.; Shigeno, M.; Miyazoe, S.; et al. Hepatic steatosis is a risk factor for hepatocellular carcinoma in patients with chronic hepatitis C virus infection. Cancer 2003, 97, 3036-3043. [CrossRef] [PubMed]

48. Yoshida, H.; Shiratori, Y.; Moriyama, M.; Arakawa, Y.; Ide, T.; Sata, M.; Inoue, O.; Yano, M.; Tanaka, M.; Fujiyama, S.; et al. Interferon therapy reduces the risk for hepatocellular carcinoma: National surveillance program of cirrhotic and noncirrhotic patients with chronic hepatitis C in Japan. IHIT Study Group. Inhibition of Hepatocarcinogenesis by Interferon Therapy. Ann. Intern. Med. 1999, 131, 174-181. [CrossRef] [PubMed]

49. Alberti, A.; Piovesan, S. Increased incidence of liver cancer after successful DAA treatment of chronic hepatitis C: Fact or fiction? Liver Int. 2017, 37, 802-808. [CrossRef] [PubMed]

50. El Kassas, M.; Funk, A.L.; Salaheldin, M.; Shimakawa, Y.; Eltabbakh, M.; Jean, K.; El Tahan, A.; Sweedy, A.T.; Afify, S.; Youssef, N.F.; et al. Increased recurrence rates of hepatocellular carcinoma after DAA therapy in a hepatitis C-infected Egyptian cohort: A comparative analysis. J. Viral Hepat. 2018, 25, 623-630. [CrossRef]

51. Sasaki, R.; Kanda, T.; Kato, N.; Yokosuka, O.; Moriyama, M. Hepatitis C virus-associated hepatocellular carcinoma after sustained virologic response. World J. Hepatol. 2018, 10, 898-906. [CrossRef]

52. Totoki, Y.; Tatsuno, K.; Covington, K.R.; Ueda, H.; Creighton, C.J.; Kato, M.; Tsuji, S.; Donehower, L.A.; Slagle, B.L.; Nakamura, H.; et al. Trans-ancestry mutational landscape of hepatocellular carcinoma genomes. Nat. Genet. 2014, 46, 1267-1273. [CrossRef]

53. Fujimoto, A.; Totoki, Y.; Abe, T.; Boroevich, K.A.; Hosoda, F.; Nguyen, H.H.; Aoki, M.; Hosono, N.; Kubo, M.; Miya, F.; et al. Whole-genome sequencing of liver cancers identifies etiological influences on mutation patterns and recurrent mutations in chromatin regulators. Nat. Genet. 2012, 44, 760-764. [CrossRef] [PubMed]

54. Huang, J.; Deng, Q.; Wang, Q.; Li, K.Y.; Dai, J.H.; Li, N.; Zhu, Z.D.; Zhou, B.; Liu, X.Y.; Liu, R.F.; et al. Exome sequencing of hepatitis B virus-associated hepatocellular carcinoma. Nat. Genet. 2012, 44, 1117-1121. [CrossRef]

55. Schulze, K.; Imbeaud, S.; Letouzé, E.; Alexandrov, L.B.; Calderaro, J.; Rebouissou, S.; Couchy, G.; Meiller, C.; Shinde, J.; Soysouvanh, F.; et al. Exome sequencing of hepatocellular carcinomas identifies new mutational signatures and potential therapeutic targets. Nat. Genet. 2015, 47, 505-511. [CrossRef] [PubMed]

56. Nault, J.C.; Mallet, M.; Pilati, C.; Calderaro, J.; Bioulac-Sage, P.; Laurent, C.; Laurent, A.; Cherqui, D.; Balabaud, C.; Zucman-Rossi, J. High frequency of telomerase reverse-transcriptase promoter somatic mutations in hepatocellular carcinoma and preneoplastic lesions. Nat. Commun. 2013, 4, 2218. [CrossRef] [PubMed]

57. Li, M.; Zhao, H.; Zhang, X.; Wood, L.D.; Anders, R.A.; Choti, M.A.; Pawlik, T.M.; Daniel, H.D.; Kannangai, R.; Offerhaus, G.J.; et al. Inactivating mutations of the chromatin remodeling gene ARID2 in hepatocellular carcinoma. Nat. Genet. 2011, 43, 828-829. [CrossRef]

58. Moore, A.; Wu, L.; Chuang, J.C.; Sun, X.; Luo, X.; Gopal, P.; Li, L.; Celen, C.; Zimmer, M.; Zhu, H. Arid1a loss drives non-alcoholic steatohepatitis in mice via epigenetic dysregulation of hepatic lipogenesis and fatty acid oxidation. Hepatology 2018. [CrossRef]

59. Nose, H.; Imazeki, F.; Ohto, M.; Omata, M. p53 gene mutations and 17p allelic deletions in hepatocellular carcinoma from Japan. Cancer 1993, 72, 355-3560. [CrossRef]

60. Imazeki, F.; Yokosuka, O.; Ohto, M.; Omata, M. Aflatoxin and p53 abnormality in duck hepatocellular carcinoma. J. Gastroenterol. Hepatol. 1995, 10, 646-649. [CrossRef]

61. Ray, R.B.; Meyer, K.; Ray, R. Suppression of apoptotic cell death by hepatitis C virus core protein. Virology 1996, 226, 176-182. [CrossRef] 
62. Ray, R.B.; Steele, R.; Meyer, K.; Ray, R. Hepatitis C virus core protein represses p21WAF1/Cip1/Sid1 promoter activity. Gene 1998, 208, 331-336. [CrossRef]

63. Fei, Q.; Shang, K.; Zhang, J.; Chuai, S.; Kong, D.; Zhou, T.; Fu, S.; Liang, Y.; Li, C.; Chen, Z.; et al. Histone methyltransferase SETDB1 regulates liver cancer cell growth through methylation of p53. Nat. Commun. 2015, 6, 8651. [CrossRef] [PubMed]

64. Wong, C.M.; Wei, L.; Law, C.T.; Ho, D.W.; Tsang, F.H.; Au, S.L.; Sze, K.M.; Lee, J.M.; Wong, C.C.; Ng, I.O. Up-regulation of histone methyltransferase SETDB1 by multiple mechanisms in hepatocellular carcinoma promotes cancer metastasis. Hepatology 2016, 63, 474-487. [CrossRef] [PubMed]

65. Kodama, T.; Newberg, J.Y.; Kodama, M.; Rangel, R.; Yoshihara, K.; Tien, J.C.; Parsons, P.H.; Wu, H.; Finegold, M.J.; Copeland, N.G.; et al. Transposon mutagenesis identifies genes and cellular processes driving epithelial-mesenchymal transition in hepatocellular carcinoma. Proc. Natl. Acad. Sci. USA 2016, 113, E3384-E3393. [CrossRef] [PubMed]

66. Harding, J.J.; Nandakumar, S.; Armenia, J.; Khalil, D.N.; Albano, M.; Ly, M.; Shia, J.; Hechtman, J.F.; Kundra, R.; El Dika, I.; et al. Prospective Genotyping of Hepatocellular Carcinoma: Clinical Implications of Next Generation Sequencing for Matching Patients to Targeted and Immune Therapies. Clin. Cancer Res. 2018. [CrossRef] [PubMed]

67. Inami, Y.; Waguri, S.; Sakamoto, A.; Kouno, T.; Nakada, K.; Hino, O.; Watanabe, S.; Ando, J.; Iwadate, M.; Yamamoto, M.; et al. Persistent activation of Nrf2 through p62 in hepatocellular carcinoma cells. J. Cell Biol. 2011, 193, 275-284. [CrossRef]

68. Zavattari, P.; Perra, A.; Menegon, S.; Kowalik, M.A.; Petrelli, A.; Angioni, M.M.; Follenzi, A.; Quagliata, L.; Ledda-Columbano, G.M.; Terracciano, L.; et al. Nrf2, but not $\beta$-catenin, mutation represents an early event in rat hepatocarcinogenesis. Hepatology 2015, 62, 851-862. [CrossRef]

69. Bartolini, D.; Dallaglio, K.; Torquato, P.; Piroddi, M.; Galli, F. Nrf2-p62 autophagy pathway and its response to oxidative stress in hepatocellular carcinoma. Transl. Res. 2018, 193, 54-71. [CrossRef]

70. Fujimoto, A.; Furuta, M.; Totoki, Y.; Tsunoda, T.; Kato, M.; Shiraishi, Y.; Tanaka, H.; Taniguchi, H.; Kawakami, Y.; Ueno, M.; et al. Whole-genome mutational landscape and characterization of noncoding and structural mutations in liver cancer. Nat. Genet. 2016, 48, 500-509. [CrossRef]

71. Kojima, H.; Yokosuka, O.; Imazeki, F.; Saisho, H.; Omata, M. Telomerase activity and telomere length in hepatocellular carcinoma and chronic liver disease. Gastroenterology 1997, 112, 493-500. [CrossRef]

72. Tokino, T.; Matsubara, K. Chromosomal sites for hepatitis B virus integration in human hepatocellular carcinoma. J. Virol. 1991, 65, 6761-6764.

73. Nagaya, T.; Nakamura, T.; Tokino, T.; Tsurimoto, T.; Imai, M.; Mayumi, T.; Kamino, K.; Yamamura, K.; Matsubara, K. The mode of hepatitis B virus DNA integration in chromosomes of human hepatocellular carcinoma. Genes Dev. 1987, 1, 773-782. [CrossRef]

74. Imazeki, F.; Omata, M.; Yokosuka, O.; Okuda, K. Integration of hepatitis B virus DNA in hepatocellular carcinoma. Cancer 1986, 58, 1055-1060. [CrossRef]

75. Wang, M.; Xi, D.; Ning, Q. Virus-induced hepatocellular carcinoma with special emphasis on HBV. Hepatol. Int. 2017, 11, 171-180. [CrossRef]

76. Meyerson, M.; Counter, C.M.; Eaton, E.N.; Ellisen, L.W.; Steiner, P.; Caddle, S.D.; Ziaugra, L.; Beijersbergen, R.L.; Davidoff, M.J.; Liu, Q.; et al. hEST2, the putative human telomerase catalytic subunit gene, is up-regulated in tumor cells and during immortalization. Cell 1997, 90, 785-795. [CrossRef]

77. Tokino, T.; Fukushige, S.; Nakamura, T.; Nagaya, T.; Murotsu, T.; Shiga, K.; Aoki, N.; Matsubara, K. Chromosomal translocation and inverted duplication associated with integrated hepatitis B virus in hepatocellular carcinomas. J. Virol. 1987, 61, 3848-3854.

78. Koike, K.; Shirakata, Y.; Yaginuma, K.; Arii, M.; Takada, S.; Nakamura, I.; Hayashi, Y.; Kawada, M.; Kobayashi, M. Oncogenic potential of hepatitis B virus. Mol. Biol. Med. 1989, 6, 151-160.

79. Kanda, T.; Yokosuka, O.; Imazeki, F.; Yamada, Y.; Imamura, T.; Fukai, K.; Nagao, K.; Saisho, H. Hepatitis B virus $\mathrm{X}$ protein (HBx)-induced apoptosis in HuH-7 cells: Influence of HBV genotype and basal core promoter mutations. Scand. J. Gastroenterol. 2004, 39, 478-485. [CrossRef]

80. Liu, H.; Shi, W.; Luan, F.; Xu, S.; Yang, F.; Sun, W.; Liu, J.; Ma, C. Hepatitis B virus X protein upregulates transcriptional activation of human telomerase reverse transcriptase. Virus Genes. 2010, 40, $174-182$. [CrossRef] 
81. Zou, S.Q.; Qu, Z.L.; Li, Z.F.; Wang, X. Hepatitis B virus X gene induces human telomerase reverse transcriptase mRNA expression in cultured normal human cholangiocytes. World J. Gastroenterol. 2004, 10, 2259-2262. [CrossRef]

82. Kojima, H.; Kaita, K.D.; Xu, Z.; Ou, J.H.; Gong, Y.; Zhang, M.; Minuk, G.Y. The absence of up-regulation of telomerase activity during regeneration after partial hepatectomy in hepatitis $B$ virus $X$ gene transgenic mice. J. Hepatol. 2003, 39, 262-268. [CrossRef]

83. Sung, W.K.; Zheng, H.; Li, S.; Chen, R.; Liu, X.; Li, Y.; Lee, N.P.; Lee, W.H.; Ariyaratne, P.N.; Tennakoon, C.; et al. Genome-wide survey of recurrent HBV integration in hepatocellular carcinoma. Nat. Genet. 2012, 44, 765-769. [CrossRef] [PubMed]

84. Nakano, M.; Kawaguchi, T.; Nakamoto, S.; Kawaguchi, A.; Kanda, T.; Imazeki, F.; Kuromatsu, R.; Sumie, S.; Satani, M.; Yamada, S.; et al. Effect of occult hepatitis B virus infection on the early-onset of hepatocellular carcinoma in patients with hepatitis C virus infection. Oncol. Rep. 2013, 30, 2049-2055. [CrossRef] [PubMed]

85. Mason, W.S.; Gill, U.S.; Litwin, S.; Zhou, Y.; Peri, S.; Pop, O.; Hong, M.L.; Naik, S.; Quaglia, A.; Bertoletti, A.; et al. HBV DNA Integration and Clonal Hepatocyte Expansion in Chronic Hepatitis B Patients Considered Immune Tolerant. Gastroenterology 2016, 151, 986-998. [CrossRef] [PubMed]

86. Kennedy, P.T.F.; Litwin, S.; Dolman, G.E.; Bertoletti, A.; Mason, W.S. Immune Tolerant Chronic Hepatitis B: The Unrecognized Risks. Viruses 2017, 9, 96. [CrossRef] [PubMed]

87. Wu, S.; Kanda, T.; Nakamoto, S.; Jiang, X.; Nakamura, M.; Sasaki, R.; Haga, Y.; Shirasawa, H.; Yokosuka, O. Cooperative effects of hepatitis B virus and TNF may play important roles in the activation of metabolic pathways through the activation of NF-kB. Int. J. Mol. Med. 2016, 38, 475-481. [CrossRef] [PubMed]

88. Xie, Y. Hepatitis B Virus-Associated Hepatocellular Carcinoma. Adv. Exp. Med. Biol. 2017, 1018, 11-21. [CrossRef]

89. Jiang, X.; Kanda, T.; Wu, S.; Nakamura, M.; Miyamura, T.; Nakamoto, S.; Banerjee, A.; Yokosuka, O. Regulation of microRNA by hepatitis B virus infection and their possible association with control of innate immunity. World J. Gastroenterol. 2014, 20, 7197-7206. [CrossRef]

90. Sarkar, N.; Panigrahi, R.; Pal, A.; Biswas, A.; Singh, S.P.; Kar, S.K.; Bandopadhyay, M.; Das, D.; Saha, D.; Kanda, T.; et al. Expression of microRNA-155 correlates positively with the expression of Toll-like receptor 7 and modulates hepatitis B virus via C/EBP- $\beta$ in hepatocytes. J. Viral Hepat. 2015, 22, 817-827. [CrossRef] [PubMed]

91. Wang, W.; Bian, H.; Li, F.; Li, X.; Zhang, D.; Sun, S.; Song, S.; Zhu, Q.; Ren, W.; Qin, C.; et al. HBeAg induces the expression of macrophage miR-155 to accelerate liver injury via promoting production of inflammatory cytokines. Cell. Mol. Life Sci. 2018, 75, 2627-2641. [CrossRef] [PubMed]

92. Wong, Q.W.; Lung, R.W.; Law, P.T.; Lai, P.B.; Chan, K.Y.; To, K.F.; Wong, N. MicroRNA-223 is commonly repressed in hepatocellular carcinoma and potentiates expression of Stathmin1. Gastroenterology 2008, 135, 257-269. [CrossRef] [PubMed]

93. Zhang, X.; Liu, S.; Hu, T.; Liu, S.; He, Y.; Sun, S. Up-regulated microRNA-143 transcribed by nuclear factor kappa B enhances hepatocarcinoma metastasis by repressing fibronectin expression. Hepatology 2009, 50, 490-499. [CrossRef] [PubMed]

94. Yang, L.; Ma, Z.; Wang, D.; Zhao, W.; Chen, L.; Wang, G. MicroRNA-602 regulating tumor suppressive gene RASSF1A is overexpressed in hepatitis B virus-infected liver and hepatocellular carcinoma. Cancer Biol. Ther. 2010, 9, 803-808. [CrossRef] [PubMed]

95. Wang, Y.; Lu, Y.; Toh, S.T.; Sung, W.K.; Tan, P.; Chow, P.; Chung, A.Y.; Jooi, L.L.; Lee, C.G. Lethal-7 is down-regulated by the hepatitis $\mathrm{B}$ virus $\mathrm{x}$ protein and targets signal transducer and activator of transcription 3. J. Hepatol. 2010, 53, 57-66. [CrossRef]

96. Huang, J.; Wang, Y.; Guo, Y.; Sun, S. Down-regulated microRNA-152 induces aberrant DNA methylation in hepatitis B virus-related hepatocellular carcinoma by targeting DNA methyltransferase 1. Hepatology 2010, 52, 60-70. [CrossRef] [PubMed]

97. Li, L.M.; Hu, Z.B.; Zhou, Z.X.; Chen, X.; Liu, F.Y.; Zhang, J.F.; Shen, H.B.; Zhang, C.Y.; Zen, K. Serum microRNA profiles serve as novel biomarkers for HBV infection and diagnosis of HBV-positive hepatocarcinoma. Cancer Res. 2010, 70, 9798-9807. [CrossRef] [PubMed]

98. Gao, P.; Wong, C.C.; Tung, E.K.; Lee, J.M.; Wong, C.M.; Ng, I.O. Deregulation of microRNA expression occurs early and accumulates in early stages of HBV-associated multistep hepatocarcinogenesis. J. Hepatol. 2011, 54, 1177-1184. [CrossRef] [PubMed] 
99. Jiang, R.; Deng, L.; Zhao, L.; Li, X.; Zhang, F.; Xia, Y.; Gao, Y.; Wang, X.; Sun, B. miR-22 promotes HBV-related hepatocellular carcinoma development in males. Clin. Cancer Res. 2011, 17, 5593-5603. [CrossRef] [PubMed]

100. Wang, C.M.; Wang, Y.; Fan, C.G.; Xu, F.F.; Sun, W.S.; Liu, Y.G.; Jia, J.H. miR-29c targets TNFAIP3, inhibits cell proliferation and induces apoptosis in hepatitis B virus-related hepatocellular carcinoma. Biochem. Biophys. Res. Commun. 2011, 411, 586-592. [CrossRef]

101. Qi, P.; Cheng, S.Q.; Wang, H.; Li, N.; Chen, Y.F.; Gao, C.F. Serum microRNAs as biomarkers for hepatocellular carcinoma in Chinese patients with chronic hepatitis B virus infection. PLoS ONE 2011, 6, e28486. [CrossRef]

102. Cardin, R.; Piciocchi, M.; Sinigaglia, A.; Lavezzo, E.; Bortolami, M.; Kotsafti, A.; Cillo, U.; Zanus, G.; Mescoli, C.; Rugge, M.; et al. Oxidative DNA damage correlates with cell immortalization and mir-92 expression in hepatocellular carcinoma. BMC Cancer 2012, 12, 177. [CrossRef]

103. Li, L.; Guo, Z.; Wang, J.; Mao, Y.; Gao, Q. Serum miR-18a: A potential marker for hepatitis B virus-related hepatocellular carcinoma screening. Dig. Dis. Sci. 2012, 57, 2910-2916. [CrossRef] [PubMed]

104. Fu, X.; Tan, D.; Hou, Z.; Hu, Z.; Liu, G. miR-338-3p is down-regulated by hepatitis B virus X and inhibits cell proliferation by targeting the 3'-UTR region of CyclinD1. Int. J. Mol. Sci. 2012, 13, 8514-8539. [CrossRef] [PubMed]

105. Yang, P.; Li, Q.J.; Feng, Y.; Zhang, Y.; Markowitz, G.J.; Ning, S.; Deng, Y.; Zhao, J.; Jiang, S.; Yuan, Y.; et al. TGF- $\beta$-miR-34a-CCL22 signaling-induced Treg cell recruitment promotes venous metastases of HBV-positive hepatocellular carcinoma. Cancer Cell 2012, 22, 291-303. [CrossRef] [PubMed]

106. Wei, X.; Xiang, T.; Ren, G.; Tan, C.; Liu, R.; Xu, X.; Wu, Z. miR-101 is down-regulated by the hepatitis B virus $\mathrm{x}$ protein and induces aberrant DNA methylation by targeting DNA methyltransferase 3A. Cell. Signal. 2013, 25, 439-446. [CrossRef]

107. Li, C.; Wang, Y.; Wang, S.; Wu, B.; Hao, J.; Fan, H.; Ju, Y.; Ding, Y.; Chen, L.; Chu, X.; et al. Hepatitis B virus mRNA-mediated miR-122 inhibition upregulates PTTG1-binding protein, which promotes hepatocellular carcinoma tumor growth and cell invasion. J. Virol. 2013, 87, 2193-2205. [CrossRef]

108. Xu, X.; Fan, Z.; Kang, L.; Han, J.; Jiang, C.; Zheng, X.; Zhu, Z.; Jiao, H.; Lin, J.; Jiang, K.; et al. Hepatitis B virus $X$ protein represses miRNA-148a to enhance tumorigenesis. J. Clin. Investig. 2013, 123, 630-645. [CrossRef]

109. Shi, C.; Xu, X. MicroRNA-22 is down-regulated in hepatitis B virus-related hepatocellular carcinoma. Biomed. Pharmacother. 2013, 67, 375-380. [CrossRef]

110. Lan, S.H.; Wu, S.Y.; Zuchini, R.; Lin, X.Z.; Su, I.J.; Tsai, T.F.; Lin, Y.J.; Wu, C.T.; Liu, H.S. Autophagy suppresses tumorigenesis of hepatitis B virus-associated hepatocellular carcinoma through degradation of microRNA-224. Hepatology 2014, 59, 505-517. [CrossRef]

111. Fu, Y.; Wei, X.; Tang, C.; Li, J.; Liu, R.; Shen, A.; Wu, Z. Circulating microRNA-101 as a potential biomarker for hepatitis B virus-related hepatocellular carcinoma. Oncol. Lett. 2013, 6, 1811-1815. [CrossRef]

112. Li, J.; Shi, W.; Gao, Y.; Yang, B.; Jing, X.; Shan, S.; Wang, Y.; Du, Z. Analysis of microRNA expression profiles in human hepatitis B virus-related hepatocellular carcinoma. Clin. Lab. 2013, 59, 1009-1015. [CrossRef] [PubMed]

113. Zhang, T.; Zhang, J.; Cui, M.; Liu, F.; You, X.; Du, Y.; Gao, Y.; Zhang, S.; Lu, Z.; Ye, L.; et al. Hepatitis B virus $X$ protein inhibits tumor suppressor miR-205 through inducing hypermethylation of miR-205 promoter to enhance carcinogenesis. Neoplasia 2013, 15, 1282-1291. [CrossRef]

114. Sheng, Y.; Li, J.; Zou, C.; Wang, S.; Cao, Y.; Zhang, J.; Huang, A.; Tang, H. Downregulation of miR-101-3p by hepatitis B virus promotes proliferation and migration of hepatocellular carcinoma cells by targeting Rab5a. Arch. Virol. 2014, 159, 2397-2410. [CrossRef] [PubMed]

115. Dang, Y.W.; Zeng, J.; He, R.Q.; Rong, M.H.; Luo, D.Z.; Chen, G. Effects of miR-152 on cell growth inhibition, motility suppression and apoptosis induction in hepatocellular carcinoma cells. Asian Pac. J. Cancer Prev. 2014, 15, 4969-4976. [CrossRef] [PubMed]

116. Lan, S.H.; Wu, S.Y.; Zuchini, R.; Lin, X.Z.; Su, I.J.; Tsai, T.F.; Lin, Y.J.; Wu, C.T.; Liu, H.S. Autophagy-preferential degradation of MIR224 participates in hepatocellular carcinoma tumorigenesis. Autophagy 2014, 10, 1687-1689. [CrossRef]

117. Meng, F.L.; Wang, W.; Jia, W.D. Diagnostic and prognostic significance of serum miR-24-3p in HBV-related hepatocellular carcinoma. Med. Oncol. 2014, 31, 177. [CrossRef] 
118. Bandopadhyay, M.; Banerjee, A.; Sarkar, N.; Panigrahi, R.; Datta, S.; Pal, A.; Singh, S.P.; Biswas, A.; Chakrabarti, S.; Chakravarty, R. Tumor suppressor micro RNA miR-145 and onco micro RNAs miR-21 and miR-222 expressions are differentially modulated by hepatitis $B$ virus $X$ protein in malignant hepatocytes. BMC Cancer 2014, 14, 721. [CrossRef] [PubMed]

119. Xing, T.J.; Jiang, D.F.; Huang, J.X.; Xu, Z.L. Expression and clinical significance of miR-122 and miR-29 in hepatitis B virus-related liver disease. Genet. Mol. Res. 2014, 13, 7912-7918. [CrossRef]

120. Zhao, Q.; Li, T.; Qi, J.; Liu, J.; Qin, C. The miR-545/374a cluster encoded in the Ftx lncRNA is overexpressed in HBV-related hepatocellular carcinoma and promotes tumorigenesis and tumor progression. PLOS ONE 2014, 9, e109782. [CrossRef]

121. Gao, H.; Liu, C. miR-429 represses cell proliferation and induces apoptosis in HBV-related HCC. Biomed. Pharmacother. 2014, 68, 943-949. [CrossRef]

122. Liu, F.Y.; Zhou, S.J.; Deng, Y.L.; Zhang, Z.Y.; Zhang, E.L.; Wu, Z.B.; Huang, Z.Y.; Chen, X.P. MiR-216b is involved in pathogenesis and progression of hepatocellular carcinoma through HBx-miR-216b-IGF2BP2 signaling pathway. Cell Death Dis. 2015, 6, e1670. [CrossRef]

123. Yu, F.; Lu, Z.; Chen, B.; Dong, P.; Zheng, J. microRNA-150: A promising novel biomarker for hepatitis B virus-related hepatocellular carcinoma. Diagn. Pathol. 2015, 10, 129. [CrossRef] [PubMed]

124. Cao, Y.; Chen, J.; Wang, D.; Peng, H.; Tan, X.; Xiong, D.; Huang, A.; Tang, H. Upregulated in Hepatitis $\mathrm{B}$ virus-associated hepatocellular carcinoma cells, miR-331-3p promotes proliferation of hepatocellular carcinoma cells by targeting ING5. Oncotarget 2015, 6, 38093-38106. [CrossRef]

125. Gao, F.; Sun, X.; Wang, L.; Tang, S.; Yan, C. Downregulation of MicroRNA-145 Caused by Hepatitis B Virus $X$ Protein Promotes Expression of CUL5 and Contributes to Pathogenesis of Hepatitis B Virus-Associated Hepatocellular Carcinoma. Cell. Physiol. Biochem. 2015, 37, 1547-1559. [CrossRef] [PubMed]

126. Shao, J.; Cao, J.; Liu, Y.; Mei, H.; Zhang, Y.; Xu, W. MicroRNA-519a promotes proliferation and inhibits apoptosis of hepatocellular carcinoma cells by targeting FOXF2. FEBS Open Bio 2015, 5, 893-899. [CrossRef] [PubMed]

127. Wang, Y.; Wang, C.M.; Jiang, Z.Z.; Yu, X.J.; Fan, C.G.; Xu, F.F.; Zhang, Q.; Li, L.I.; Li, R.F.; Sun, W.S.; et al. MicroRNA-34c targets TGFB-induced factor homeobox 2, represses cell proliferation and induces apoptosis in hepatitis B virus-related hepatocellular carcinoma. Oncol. Lett. 2015, 10, 3095-3102. [CrossRef]

128. Ghosh, A.; Ghosh, A.; Datta, S.; Dasgupta, D.; Das, S.; Ray, S.; Gupta, S.; Datta, S.; Chowdhury, A.; Chatterjee, R.; et al. Hepatic miR-126 is a potential plasma biomarker for detection of hepatitis B virus infected hepatocellular carcinoma. Int. J. Cancer 2016, 138, 2732-2744. [CrossRef] [PubMed]

129. Chen, Y.; Dong, X.; Yu, D.; Wang, X. Serum miR-96 is a promising biomarker for hepatocellular carcinoma in patients with chronic hepatitis B virus infection. Int. J. Clin. Exp. Med. 2015, 8, 18462-18468. [PubMed]

130. Chen, S.; Chen, H.; Gao, S.; Qiu, S.; Zhou, H.; Yu, M.; Tu, J. Differential expression of plasma microRNA-125b in hepatitis $B$ virus-related liver diseases and diagnostic potential for hepatitis B virus-induced hepatocellular carcinoma. Hepatol. Res. 2017, 47, 312-320. [CrossRef] [PubMed]

131. Yen, C.S.; Su, Z.R.; Lee, Y.P.; Liu, I.T.; Yen, C.J. miR-106b promotes cancer progression in hepatitis B virus-associated hepatocellular carcinoma. World J. Gastroenterol. 2016, 22, 5183-5192. [CrossRef]

132. Kong, X.X.; Lv, Y.R.; Shao, L.P.; Nong, X.Y.; Zhang, G.L.; Zhang, Y.; Fan, H.X.; Liu, M.; Li, X.; Tang, H. HBx-induced MiR-1269b in NF-kB dependent manner upregulates cell division cycle 40 homolog (CDC40) to promote proliferation and migration in hepatoma cells. J. Transl. Med. 2016, 14, 189. [CrossRef]

133. Liu, X.; Zhang, Y.; Wang, P.; Wang, H.; Su, H.; Zhou, X.; Zhang, L. HBX Protein-Induced Downregulation of microRNA-18a is Responsible for Upregulation of Connective Tissue Growth Factor in HBV Infection-Associated Hepatocarcinoma. Med. Sci. Monit. 2016, 22, 2492-2500. [CrossRef]

134. Qiao, D.D.; Yang, J.; Lei, X.F.; Mi, G.L.; Li, S.L.; Li, K.; Xu, C.Q.; Yang, H.L. Expression of microRNA-122 and microRNA-22 in HBV-related liver cancer and the correlation with clinical features. Eur. Rev. Med. Pharmacol. Sci. 2017, 21, 742-747. [PubMed]

135. Qin, X.; Chen, J.; Wu, L.; Liu, Z. MiR-30b-5p acts as a tumor suppressor, repressing cell proliferation and cell cycle in human hepatocellular carcinoma. Biomed. Pharmacother. 2017, 89, 742-750. [CrossRef] [PubMed]

136. Bai, P.S.; Xia, N.; Sun, H.; Kong, Y. Pleiotrophin, a target of miR-384, promotes proliferation, metastasis and lipogenesis in HBV-related hepatocellular carcinoma. J. Cell. Mol. Med. 2017, 21, 3023-3043. [CrossRef] [PubMed] 
137. Li, G.; Zhang, W.; Gong, L.; Huang, X. MicroRNA-125a-5p Inhibits Cell Proliferation and Induces Apoptosis in Hepatitis B Virus-Related Hepatocellular Carcinoma by Downregulation of ErbB3. Oncol. Res. 2017. [CrossRef]

138. Zhao, Q.; Sun, X.; Liu, C.; Li, T.; Cui, J.; Qin, C. Expression of the microRNA-143/145 cluster is decreased in hepatitis $\mathrm{B}$ virus-associated hepatocellular carcinoma and may serve as a biomarker for tumorigenesis in patients with chronic hepatitis B. Oncol. Lett. 2018, 15, 6115-6122. [CrossRef] [PubMed]

139. Quoc, N.B.; Phuong, N.D.N.; Ngan, T.K.; Linh, N.T.M.; Cuong, P.H.; Chau, N.N.B. Expression of Plasma hsa-miR122 in HBV-Related Hepatocellular Carcinoma (HCC) in Vietnamese Patients. Microrna 2018, 7, 92-99. [CrossRef] [PubMed]

140. Jones, K.R.; Nabinger, S.C.; Lee, S.; Sahu, S.S.; Althouse, S.; Saxena, R.; Johnson, M.S.; Chalasani, N.; Gawrieh, S.; Kota, J. Lower expression of tumor microRNA-26a is associated with higher recurrence in patients with hepatocellular carcinoma undergoing surgical treatment. J. Surg. Oncol. 2018, 118, 431-439. [CrossRef] [PubMed]

141. Yang, L.; Guo, Y.; Liu, X.; Wang, T.; Tong, X.; Lei, K.; Wang, J.; Huang, D.; Xu, Q. The tumor suppressive miR-302c-3p inhibits migration and invasion of hepatocellular carcinoma cells by targeting TRAF4. J. Cancer 2018, 9, 2693-2701. [CrossRef]

142. Chen, Y.; Zhao, Z.X.; Huang, F.; Yuan, X.W.; Deng, L.; Tang, D. MicroRNA-1271 functions as a potential tumor suppressor in hepatitis B virus-associated hepatocellular carcinoma through the AMPK signaling pathway by binding to CCNA1. J. Cell. Physiol. 2018. [CrossRef]

143. Qiu, L.; Wang, T.; Xu, X.; Wu, Y.; Tang, Q.; Chen, K. Long Non-Coding RNAs in Hepatitis B Virus-Related Hepatocellular Carcinoma: Regulation, Functions, and Underlying Mechanisms. Int. J. Mol. Sci. 2017, 18, 2505. [CrossRef]

144. Cui, S.; Qian, Z.; Chen, Y.; Li, L.; Li, P.; Ding, H. Screening of up- and downregulation of circRNAs in HBV-related hepatocellular carcinoma by microarray. Oncol. Lett. 2018, 15, 423-432. [CrossRef] [PubMed]

145. Wang, S.; Cui, S.; Zhao, W.; Qian, Z.; Liu, H.; Chen, Y.; Lv, F.; Ding, H.G. Screening and bioinformatics analysis of circular RNA expression profiles in hepatitis B-related hepatocellular carcinoma. Cancer Biomark. 2018, 22, 631-640. [CrossRef]

146. Matsuda, Y.; Ichida, T.; Genda, T.; Yamagiwa, S.; Aoyagi, Y.; Asakura, H. Loss of p16 contributes to p27 sequestration by cyclin $\mathrm{D}(1)$-cyclin-dependent kinase 4 complexes and poor prognosis in hepatocellular carcinoma. Clin. Cancer Res. 2003, 9, 3389-3396. [PubMed]

147. Pezzuto, F.; Buonaguro, L.; Buonaguro, F.M.; Tornesello, M.L. The Role of Circulating Free DNA and MicroRNA in Non-Invasive Diagnosis of HBV- and HCV-Related Hepatocellular Carcinoma. Int. J. Mol. Sci. 2018, 19, 1007. [CrossRef]

148. Tian, Y.; Ou, J.H. Genetic and epigenetic alterations in hepatitis B virus-associated hepatocellular carcinoma. Virol. Sin. 2015, 30, 85-91. [CrossRef] [PubMed]

149. Wu, S.; Kanda, T.; Imazeki, F.; Arai, M.; Yonemitsu, Y.; Nakamoto, S.; Fujiwara, K.; Fukai, K.; Nomura, F.; Yokosuka, O. Hepatitis B virus e antigen downregulates cytokine production in human hepatoma cell lines. Viral Immunol. 2010, 23, 467-476. [CrossRef]

150. Hadziyannis, E.; Laras, A. Viral Biomarkers in Chronic HBeAg Negative HBV Infection. Genes 2018, 9, 469. [CrossRef] [PubMed]

151. Hildt, E.; Hofschneider, P.H. The PreS2 activators of the hepatitis B virus: Activators of tumour promoter pathways. Recent Results Cancer Res. 1998, 154, 315-329. [PubMed]

152. Liu, P.; Zhang, H.; Liang, X.; Ma, H.; Luan, F.; Wang, B.; Bai, F.; Gao, L.; Ma, C. HBV preS2 promotes the expression of TAZ via miRNA-338-3p to enhance the tumorigenesis of hepatocellular carcinoma. Oncotarget 2015, 6, 29048-29059. [CrossRef] [PubMed]

153. Wang, M.L.; Wu, D.B.; Tao, Y.C.; Chen, L.L.; Liu, C.P.; Chen, E.Q.; Tang, H. The truncated mutant HBsAg expression increases the tumorigenesis of hepatitis B virus by regulating TGF- $\beta$ /Smad signaling pathway. Virol. J. 2018, 15, 61. [CrossRef] [PubMed]

154. Song, J.; Zhang, X.; Ge, Q.; Yuan, C.; Chu, L.; Liang, H.F.; Liao, Z.; Liu, Q.; Zhang, Z.; Zhang, B. CRISPR/Cas9-mediated knockout of HBsAg inhibits proliferation and tumorigenicity of HBV-positive hepatocellular carcinoma cells. J. Cell. Biochem. 2018, 119, 8419-8431. [CrossRef] [PubMed]

155. Kanda, T.; Wu, S.; Sasaki, R.; Nakamura, M.; Haga, Y.; Jiang, X.; Nakamoto, S.; Yokosuka, O. HBV Core Protein Enhances Cytokine Production. Diseases 2015, 3, 213-220. [CrossRef] [PubMed] 
156. Wu, S.; Kanda, T.; Imazeki, F.; Nakamoto, S.; Tanaka, T.; Arai, M.; Roger, T.; Shirasawa, H.; Nomura, F.; Yokosuka, O. Hepatitis B virus e antigen physically associates with receptor-interacting serine/threonine protein kinase 2 and regulates IL-6 gene expression. J. Infect. Dis. 2012, 206, 415-420. [CrossRef] [PubMed]

157. Chen, M.T.; Billaud, J.N.; Sällberg, M.; Guidotti, L.G.; Chisari, F.V.; Jones, J.; Hughes, J.; Milich, D.R. A function of the hepatitis B virus precore protein is to regulate the immune response to the core antigen. Proc. Natl. Acad. Sci. USA 2004, 101, 14913-14918. [CrossRef] [PubMed]

158. Chen, M.; Sällberg, M.; Hughes, J.; Jones, J.; Guidotti, L.G.; Chisari, F.V.; Billaud, J.N.; Milich, D.R. Immune tolerance split between hepatitis B virus precore and core proteins. J. Virol. 2005, 79, 3016-3027. [CrossRef]

159. Yaginuma, K.; Kobayashi, H.; Kobayashi, M.; Morishima, T.; Matsuyama, K.; Koike, K. Multiple integration site of hepatitis B virus DNA in hepatocellular carcinoma and chronic active hepatitis tissues from children. J. Virol. 1987, 61, 1808-1813.

160. Zhou, Y.Z.; Butel, J.S.; Li, P.J.; Finegold, M.J.; Melnick, J.L. Integrated state of subgenomic fragments of hepatitis B virus DNA in hepatocellular carcinoma from mainland China. J. Natl. Cancer Inst. 1987, 79, 223-231.

161. Kim, C.M.; Koike, K.; Saito, I.; Miyamura, T.; Jay, G. HBx gene of hepatitis B virus induces liver cancer in transgenic mice. Nature 1991, 351, 317-320. [CrossRef]

162. Wollersheim, M.; Debelka, U.; Hofschneider, P.H. A transactivating function encoded in the hepatitis B virus $\mathrm{X}$ gene is conserved in the integrated state. Oncogene 1988, 3, 545-552. [PubMed]

163. Kekulé, A.S.; Lauer, U.; Weiss, L.; Luber, B.; Hofschneider, P.H. Hepatitis B virus transactivator HBx uses a tumour promoter signalling pathway. Nature 1993, 361, 742-745. [CrossRef]

164. Choi, B.H.; Choi, M.; Jeon, H.Y.; Rho, H.M. Hepatitis B viral X protein overcomes inhibition of E2F1 activity by $\mathrm{pRb}$ on the human $\mathrm{Rb}$ gene promoter. DNA Cell Biol. 2001, 20, 75-80. [CrossRef]

165. Staib, F.; Hussain, S.P.; Hofseth, L.J.; Wang, X.W.; Harris, C.C. TP53 and liver carcinogenesis. Hum. Mutat. 2003, 21, 201-216. [CrossRef] [PubMed]

166. Cha, M.Y.; Kim, C.M.; Park, Y.M.; Ryu, W.S. Hepatitis B virus X protein is essential for the activation of Wnt/beta-catenin signaling in hepatoma cells. Hepatology 2004, 39, 1683-1693. [CrossRef]

167. Longato, L.; de la Monte, S.; Kuzushita, N.; Horimoto, M.; Rogers, A.B.; Slagle, B.L.; Wands, J.R. Overexpression of insulin receptor substrate- 1 and hepatitis Bx genes causes premalignant alterations in the liver. Hepatology 2009, 49, 1935-1943. [CrossRef] [PubMed]

168. Keng, V.W.; Tschida, B.R.; Bell, J.B.; Largaespada, D.A. Modeling hepatitis B virus X-induced hepatocellular carcinoma in mice with the Sleeping Beauty transposon system. Hepatology 2011, 53, 781-790. [CrossRef]

169. Wang, C.; Yang, W.; Yan, H.X.; Luo, T.; Zhang, J.; Tang, L.; Wu, F.Q.; Zhang, H.L.; Yu, L.X.; Zheng, L.Y.; et al. Hepatitis B virus $X(\mathrm{HBx})$ induces tumorigenicity of hepatic progenitor cells in 3,5-diethoxycarbonyl-1,4-dihydrocollidine-treated HBx transgenic mice. Hepatology 2012, 55, 108-120. [CrossRef]

170. Von Olshausen, G.; Quasdorff, M.; Bester, R.; Arzberger, S.; Ko, C.; van de Klundert, M.; Zhang, K.; Odenthal, M.; Ringelhan, M.; Niessen, C.M.; et al. Hepatitis B virus promotes $\beta$-catenin-signalling and disassembly of adherens junctions in a Src kinase dependent fashion. Oncotarget 2018, 9, 33947-33960. [CrossRef]

171. Singh, A.K.; Swarnalatha, M.; Kumar, V. c-ETS1 facilitates G1/S-phase transition by up-regulating cyclin E and CDK2 genes and cooperates with hepatitis B virus X protein for their deregulation. J. Biol. Chem. 2011, 286, 21961-21970. [CrossRef]

172. Luo, L.; Chen, S.; Gong, Q.; Luo, N.; Lei, Y.; Guo, J.; He, S. Hepatitis B virus X protein modulates remodelling of minichromosomes related to hepatitis B virus replication in HepG2 cells. Int. J. Mol. Med. 2013, 31, 197-204. [CrossRef] [PubMed]

173. Saeed, U.; Kim, J.; Piracha, Z.Z.; Kwon, H.; Jung, J.; Chwae, Y.J.; Park, S.; Shin, H.J.; Kim, K. Parvulin 14 and parvulin 17 bind to $\mathrm{HBx}$ and cccDNA and upregulate HBV replication from cccDNA to virion in a HBx-dependent manner. J. Virol. 2019, 93, e01840-18. [CrossRef] [PubMed]

174. Swarnalatha, M.; Singh, A.K.; Kumar, V. Promoter occupancy of MLL1 histone methyltransferase seems to specify the proliferative and apoptotic functions of E2F1 in a tumour microenvironment. J. Cell Sci. 2013, 126, 4636-4646. [CrossRef] [PubMed] 
175. Huang, Y.H.; Tseng, Y.H.; Lin, W.R.; Hung, G.; Chen, T.C.; Wang, T.H.; Lee, W.C.; Yeh, C.T. HBV polymerase overexpression due to large core gene deletion enhances hepatoma cell growth by binding inhibition of microRNA-100. Oncotarget 2016, 7, 9448-9461. [CrossRef] [PubMed]

176. Chung, H.J.; Chen, X.; Yu, Y.; Lee, H.K.; Song, C.H.; Choe, H.; Lee, S.; Kim, H.J.; Hong, S.T. A critical role of hepatitis B virus polymerase in cirrhosis, hepatocellular carcinoma, and steatosis. FEBS Open Bio 2017, 8, 130-145. [CrossRef]

177. Kakumu, S.; Okumura, A.; Ishikawa, T.; Yano, M.; Enomoto, A.; Nishimura, H.; Yoshioka, K.; Yoshika, Y. Serum levels of IL-10, IL-15 and soluble tumour necrosis factor-alpha (TNF-alpha) receptors in type C chronic liver disease. Clin. Exp. Immunol. 1997, 109, 458-463. [CrossRef]

178. Kanda, T.; Yokosuka, O.; Omata, M. Hepatitis C virus and hepatocellular carcinoma. Biology 2013, 2, $304-316$. [CrossRef]

179. Braconi, C.; Valeri, N.; Gasparini, P.; Huang, N.; Taccioli, C.; Nuovo, G.; Suzuki, T.; Croce, C.M.; Patel, T. Hepatitis $C$ virus proteins modulate microRNA expression and chemosensitivity in malignant hepatocytes. Clin. Cancer Res. 2010, 16, 957-966. [CrossRef]

180. Zhang, Y.; Wei, W.; Cheng, N.; Wang, K.; Li, B.; Jiang, X.; Sun, S. Hepatitis C virus-induced up-regulation of microRNA-155 promotes hepatocarcinogenesis by activating Wnt signaling. Hepatology 2012, 56, 1631-1640. [CrossRef]

181. Hsu, S.H.; Wang, B.; Kota, J.; Yu, J.; Costinean, S.; Kutay, H.; Yu, L.; Bai, S.; La Perle, K.; Chivukula, R.R.; et al. Essential metabolic, anti-inflammatory, and anti-tumorigenic functions of miR-122 in liver. J. Clin. Investig. 2012, 122, 2871-2883. [CrossRef]

182. Zhao, L.; Li, F.; Taylor, E.W. Can tobacco use promote HCV-induced miR-122 hijacking and hepatocarcinogenesis? Med. Hypotheses 2013, 80, 131-133. [CrossRef] [PubMed]

183. Salvi, A.; Abeni, E.; Portolani, N.; Barlati, S.; De Petro, G. Human hepatocellular carcinoma cell-specific miRNAs reveal the differential expression of miR-24 and miR-27a in cirrhotic/non-cirrhotic HCC. Int. J. Oncol. 2013, 42, 391-402. [CrossRef] [PubMed]

184. Elfimova, N.; Sievers, E.; Eischeid, H.; Kwiecinski, M.; Noetel, A.; Hunt, H.; Becker, D.; Frommolt, P.; Quasdorff, M.; Steffen, H.M.; et al. Control of mitogenic and motogenic pathways by miR-198, diminishing hepatoma cell growth and migration. Biochim. Biophys. Acta 2013, 1833, 1190-1198. [CrossRef] [PubMed]

185. Thomas, M.; Deiters, A. MicroRNA miR-122 as a therapeutic target for oligonucleotides and small molecules. Curr Med Chem. 2013, 20, 3629-3640. [CrossRef] [PubMed]

186. Huang, S.; Xie, Y.; Yang, P.; Chen, P.; Zhang, L. HCV core protein-induced down-regulation of microRNA-152 promoted aberrant proliferation by regulating Wnt1 in HepG2 cells. PLoS ONE 2014, 9, e81730. [CrossRef] [PubMed]

187. Mukherjee, A.; Shrivastava, S.; Bhanja Chowdhury, J.; Ray, R.; Ray, R.B. Transcriptional suppression of miR-181c by hepatitis C virus enhances homeobox A1 expression. J. Virol. 2014, 88, 7929-7940. [CrossRef]

188. Xu, G.; Yang, F.; Ding, C.L.; Wang, J.; Zhao, P.; Wang, W.; Ren, H. MiR-221 accentuates IFN's anti-HCV effect by downregulating SOCS1 and SOCS3. Virology 2014, 462-463, 343-350. [CrossRef]

189. Pan, L.; Ren, F.; Rong, M.; Dang, Y.; Luo, Y.; Luo, D.; Chen, G. Correlation between down-expression of miR-431 and clinicopathological significance in HCC tissues. Clin. Transl. Oncol. 2015, 17, 557-563. [CrossRef]

190. El-Abd, N.E.; Fawzy, N.A.; El-Sheikh, S.M.; Soliman, M.E. Circulating miRNA-122, miRNA-199a, and miRNA-16 as Biomarkers for Early Detection of Hepatocellular Carcinoma in Egyptian Patients with Chronic Hepatitis C Virus Infection. Mol. Diagn. Ther. 2015, 19, 213-220. [CrossRef]

191. Devhare, P.B.; Steele, R.; Di Bisceglie, A.M.; Kaplan, D.E.; Ray, R.B. Differential Expression of MicroRNAs in Hepatitis C Virus-Mediated Liver Disease Between African Americans and Caucasians: Implications for Racial Health Disparities. Gene Expr. 2017, 17, 89-98. [CrossRef]

192. Shiu, T.Y.; Shih, Y.L.; Feng, A.C.; Lin, H.H.; Huang, S.M.; Huang, T.Y.; Hsieh, C.B.; Chang, W.K.; Hsieh, T.Y. HCV core inhibits hepatocellular carcinoma cell replicative senescence through downregulating microRNA-138 expression. J. Mol. Med. 2017, 95, 629-639. [CrossRef]

193. Shaker, O.; Alhelf, M.; Morcos, G.; Elsharkawy, A. miRNA-101-1 and miRNA-221 expressions and their polymorphisms as biomarkers for early diagnosis of hepatocellular carcinoma. Infect. Genet. Evol. 2017, 51, 173-181. [CrossRef] [PubMed] 
194. Shehata, R.H.; Abdelmoneim, S.S.; Osman, O.A.; Hasanain, A.F.; Osama, A.; Abdelmoneim, S.S.; Toraih, E.A. Deregulation of miR-34a and Its Chaperon Hsp70 in Hepatitis C virus-Induced Liver Cirrhosis and Hepatocellular Carcinoma Patients. Asian Pac. J. Cancer Prev. 2017, 18, 2395-2401. [PubMed]

195. Sur, S.; Sasaki, R.; Devhare, P.; Steele, R.; Ray, R.; Ray, R.B. Association between MicroRNA-373 and Long Noncoding RNA NORAD in Hepatitis C Virus-Infected Hepatocytes Impairs Wee1 Expression for Growth Promotion. J. Virol. 2018, 92, e01215-18. [CrossRef] [PubMed]

196. Rashad, N.M.; El-Shal, A.S.; Shalaby, S.M.; Mohamed, S.Y. Serum miRNA-27a and miRNA-18b as potential predictive biomarkers of hepatitis $C$ virus-associated hepatocellular carcinoma. Mol. Cell. Biochem. 2018, 447, 125-136. [CrossRef]

197. Hou, W.; Bonkovsky, H.L. Non-coding RNAs in hepatitis C-induced hepatocellular carcinoma: Dysregulation and implications for early detection, diagnosis and therapy. World J. Gastroenterol. 2013, 19, 7836-7845. [CrossRef] [PubMed]

198. Zhang, H.; Zhu, C.; Zhao, Y.; Li, M.; Wu, L.; Yang, X.; Wan, X.; Wang, A.; Zhang, M.Q.; Sang, X.; et al. Long non-coding RNA expression profiles of hepatitis $C$ virus-related dysplasia and hepatocellular carcinoma. Oncotarget 2015, 6, 43770-43778. [CrossRef] [PubMed]

199. Kamel, M.M.; Matboli, M.; Sallam, M.; Montasser, I.F.; Saad, A.S.; El-Tawdi, A.H.F. Investigation of long noncoding RNAs expression profile as potential serum biomarkers in patients with hepatocellular carcinoma. Transl. Res. 2016, 168, 134-145. [CrossRef] [PubMed]

200. Fu, N.; Niu, X.; Wang, Y.; Du, H.; Wang, B.; Du, J.; Li, Y.; Wang, R.; Zhang, Y.; Zhao, S.; et al. Role of LncRNA-activated by transforming growth factor beta in the progression of hepatitis $\mathrm{C}$ virus-related liver fibrosis. Discov. Med. 2016, 22, 29-42.

201. Kanda, T.; Tada, M.; Imazeki, F.; Yokosuka, O.; Nagao, K.; Saisho, H. 5-aza-2'-deoxycytidine sensitizes hepatoma and pancreatic cancer cell lines. Oncol. Rep. 2005, 14, 975-979. [CrossRef]

202. Ray, R.B.; Lagging, L.M.; Meyer, K.; Ray, R. Hepatitis C virus core protein cooperates with ras and transforms primary rat embryo fibroblasts to tumorigenic phenotype. J. Virol. 1996, 70, 4438-4443. [PubMed]

203. Moriya, K.; Fujie, H.; Shintani, Y.; Yotsuyanagi, H.; Tsutsumi, T.; Ishibashi, K.; Matsuura, Y.; Kimura, S.; Miyamura, T.; Koike, K. The core protein of hepatitis $\mathrm{C}$ virus induces hepatocellular carcinoma in transgenic mice. Nat. Med. 1998, 4, 1065-1067. [CrossRef]

204. Kanda, T.; Steele, R.; Ray, R.; Ray, R.B. Hepatitis C virus core protein augments androgen receptor-mediated signaling. J. Virol. 2008, 82, 11066-11072. [CrossRef] [PubMed]

205. Ghosh, A.K.; Majumder, M.; Steele, R.; Meyer, K.; Ray, R.; Ray, R.B. Hepatitis C virus NS5A protein protects against TNF-alpha mediated apoptotic cell death. Virus Res. 2000, 67, 173-178. [CrossRef]

206. Majumder, M.; Ghosh, A.K.; Steele, R.; Ray, R.; Ray, R.B. Hepatitis C virus NS5A physically associates with p53 and regulates p21/waf1 gene expression in a p53-dependent manner. J. Virol. 2001, 75, 1401-1407. [CrossRef] [PubMed]

207. Imazeki, F.; Yokosuka, O.; Fukai, K.; Kanda, T.; Kojima, H.; Saisho, H. Prevalence of diabetes mellitus and insulin resistance in patients with chronic hepatitis C: Comparison with hepatitis B virus-infected and hepatitis C virus-cleared patients. Liver Int. 2008, 28, 355-362. [CrossRef] [PubMed]

208. Neuschwander-Tetri, B.A.; Clark, J.M.; Bass, N.M.; Van Natta, M.L.; Unalp-Arida, A.; Tonascia, J.; Zein, C.O.; Brunt, E.M.; Kleiner, D.E.; McCullough, A.J.; et al. NASH Clinical Research Network. Clinical, laboratory and histological associations in adults with nonalcoholic fatty liver disease. Hepatology 2010, 52, 913-924. [CrossRef] [PubMed]

209. Haga, Y.; Kanda, T.; Sasaki, R.; Nakamura, M.; Nakamoto, S.; Yokosuka, O. Nonalcoholic fatty liver disease and hepatic cirrhosis: Comparison with viral hepatitis-associated steatosis. World J. Gastroenterol. 2015, 21, 12989-12995. [CrossRef] [PubMed]

210. Kawaguchi, T.; Yoshida, T.; Harada, M.; Hisamoto, T.; Nagao, Y.; Ide, T.; Taniguchi, E.; Kumemura, H.; Hanada, S.; Maeyama, M.; et al. Hepatitis C virus down-regulates insulin receptor substrates 1 and 2 through up-regulation of suppressor of cytokine signaling 3. Am. J. Pathol. 2004, 165, 1499-1508. [CrossRef]

211. Miyamoto, H.; Moriishi, K.; Moriya, K.; Murata, S.; Tanaka, K.; Suzuki, T.; Miyamura, T.; Koike, K.; Matsuura, Y. Involvement of the PA28gamma-dependent pathway in insulin resistance induced by hepatitis C virus core protein. J. Virol. 2007, 81, 1727-1735. [CrossRef] 
212. Banerjee, S.; Saito, K.; Ait-Goughoulte, M.; Meyer, K.; Ray, R.B.; Ray, R. Hepatitis C virus core protein upregulates serine phosphorylation of insulin receptor substrate-1 and impairs the downstream akt/protein kinase B signaling pathway for insulin resistance. J. Virol. 2008, 82, 2606-2612. [CrossRef] [PubMed]

213. Banerjee, A.; Meyer, K.; Mazumdar, B.; Ray, R.B.; Ray, R. Hepatitis C virus differentially modulates activation of forkhead transcription factors and insulin-induced metabolic gene expression. J. Virol. 2010, 84, 5936-5946. [CrossRef] [PubMed]

214. Bose, S.K.; Shrivastava, S.; Meyer, K.; Ray, R.B.; Ray, R. Hepatitis C virus activates the mTOR/S6K1 signaling pathway in inhibiting IRS-1 function for insulin resistance. J. Virol. 2012, 86, 6315-6322. [CrossRef] [PubMed]

215. Tanaka, S.; Wands, J.R. Insulin receptor substrate 1 overexpression in human hepatocellular carcinoma cells prevents transforming growth factor beta1-induced apoptosis. Cancer Res. 1996, 56, 3391-3394. [PubMed]

216. Qadri, I.; Choudhury, M.; Rahman, S.M.; Knotts, T.A.; Janssen, R.C.; Schaack, J.; Iwahashi, M.; Puljak, L.; Simon, F.R.; Kilic, G.; et al. Increased phosphoenolpyruvate carboxykinase gene expression and steatosis during hepatitis $C$ virus subgenome replication: Role of nonstructural component 5A and CCAAT/enhancer-binding protein $\beta$. J. Biol. Chem. 2012, 287, 37340-37351. [CrossRef]

217. Parvaiz, F.; Manzoor, S.; Iqbal, J.; McRae, S.; Javed, F.; Ahmed, Q.L.; Waris, G. Hepatitis C virus nonstructural protein 5A favors upregulation of gluconeogenic and lipogenic gene expression leading towards insulin resistance: A metabolic syndrome. Arch. Virol. 2014, 159, 1017-1025. [CrossRef] [PubMed]

218. Parvaiz, F.; Manzoor, S.; Iqbal, J.; Sarkar-Dutta, M.; Imran, M.; Waris, G. Hepatitis C virus NS5A promotes insulin resistance through IRS-1 serine phosphorylation and increased gluconeogenesis. World J. Gastroenterol. 2015, 21, 12361-12369. [CrossRef]

219. Kwon, Y.C.; Bose, S.K.; Steele, R.; Meyer, K.; Di Bisceglie, A.M.; Ray, R.B.; Ray, R. Promotion of Cancer Stem-Like Cell Properties in Hepatitis C Virus-Infected Hepatocytes. J. Virol. 2015, 89, 11549-11556. [CrossRef]

220. Kwon, Y.C.; Sasaki, R.; Meyer, K.; Ray, R. Hepatitis C Virus Core Protein Modulates Endoglin (CD105) Signaling Pathway for Liver Pathogenesis. J. Virol. 2017, 91, e01235-17. [CrossRef]

221. Uthaya Kumar, D.B.; Chen, C.L.; Liu, J.C.; Feldman, D.E.; Sher, L.S.; French, S.; DiNorcia, J.; French, S.W.; Naini, B.V.; Junrungsee, S.; et al. TLR4 Signaling via NANOG Cooperates with STAT3 to Activate Twist1 and Promote Formation of Tumor-Initiating Stem-Like Cells in Livers of Mice. Gastroenterology 2016, 150, 707-719. [CrossRef]

222. Kudo, M. Systemic Therapy for Hepatocellular Carcinoma: Latest Advances. Cancers 2018, 10, 412. [CrossRef] [PubMed]

223. Okazaki, T.; Honjo, T. PD-1 and PD-1 ligands: From discovery to clinical application. Int. Immunol. 2007, 19, 813-824. [CrossRef] [PubMed]

224. Iwai, Y.; Ishida, M.; Tanaka, Y.; Okazaki, T.; Honjo, T.; Minato, N. Involvement of PD-L1 on tumor cells in the escape from host immune system and tumor immunotherapy by PD-L1 blockade. Proc. Natl. Acad. Sci. USA 2002, 99, 12293-12297. [CrossRef] [PubMed]

225. Leach, D.R.; Krummel, M.F.; Allison, J.P. Enhancement of antitumor immunity by CTLA-4 blockade. Science 1996, 271, 1734-1736. [CrossRef] [PubMed]

(C) 2019 by the authors. Licensee MDPI, Basel, Switzerland. This article is an open access article distributed under the terms and conditions of the Creative Commons Attribution (CC BY) license (http://creativecommons.org/licenses/by/4.0/). 